Portland State University

PDXScholar

$5-1976$

\title{
Mary's River Kalapuyan: A Descriptive Phonology
}

Yvonne P. Hajda

Portland State University

Follow this and additional works at: https://pdxscholar.library.pdx.edu/open_access_etds

Part of the Linguistic Anthropology Commons

Let us know how access to this document benefits you.

\section{Recommended Citation}

Hajda, Yvonne P., "Mary's River Kalapuyan: A Descriptive Phonology" (1976). Dissertations and Theses.

Paper 2491.

https://doi.org/10.15760/etd.2488

This Thesis is brought to you for free and open access. It has been accepted for inclusion in Dissertations and Theses by an authorized administrator of PDXScholar. Please contact us if we can make this document more accessible: pdxscholar@pdx.edu. 
AN ABSTRACT OF THE THESIS OF Yvonne P. Hajda for the Master of Arts in Anthropology presented May 11, 1976.

Title: Mary's River Kalapuyan: A Descriptive Phonology .

APPROVED BY MEMBERS OF THE THESIS COMMITTEE:

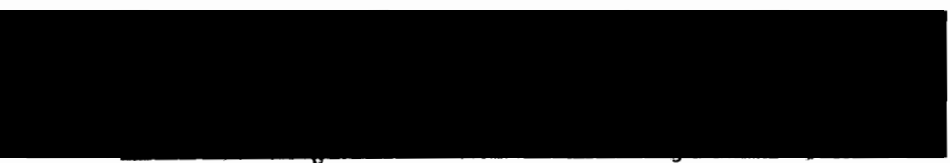

Wayne Suttles, Chairman

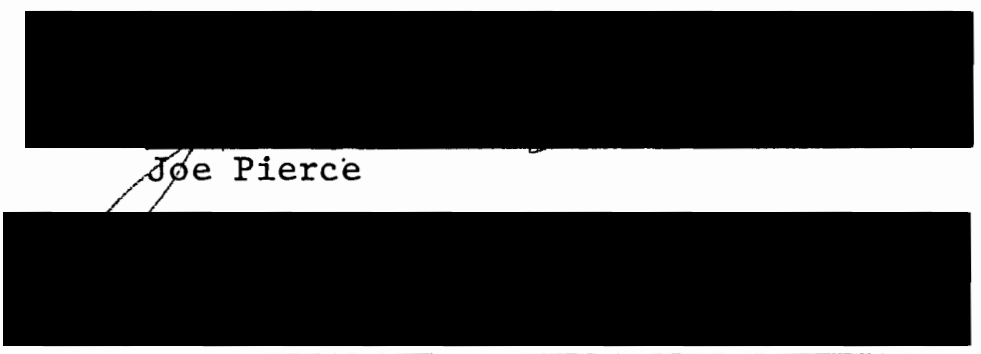

David H. French

The thesis is an attempt to apply procedures of descriptive linguistic analysis to a body of material phonetically transcribed by Leo $\mathrm{J}$. Frachtenberg in the Mary's River dialect of the central Kalapuyan language. In 1913-14, Frachtenberg collected thirteen volumes of myth texts in Mary's River, twelve from William Hartless and one from Grace Wheeler; in addition, there were notes to the texts, three volumes of grammatical notes, and some ethnographic material. The phonetic transcription was. carried out in the pre-phonemic tradition of recording everything the speaker said as accurately as possible. There was no attempt to elicit forms in a manner which woüld establish which sounds were "the. same" to the speaker, resulting in a considerable proliferation of variations of 
forms.

The main methodological problem, therefore, has been to sort out phonetic variation and phonemic contrast: This task was more difficult because no complete morphemic analysis exists as yet, so that morphophonemic alternations created additional complications. My method consisted first of tallying the forms that occurred, to establish those variants found most frequently (modal forms). The modal forms were examined to discover patterns of contrast and complementary distribution; those variants of forms which were not modally distributed, and single examples, were then compared to help confirm or modify the emerging phonemic patterns.

I arrived at a system of 21 consonants, six vowels, four diphthongs, and phonemic stress. This includes two obstruent series, glottalized and unglottalized, five fricatives, three resonants; and two glides. The vowels are high to mid front, low center, and high to mid back, with length distinctive. One pair of diphthongs is also distinguished by length; the others involve non-phonemic length. Consonant clusters are limited to two members initially and finally.

A number of uncertainties remain. These include the behavior of glottal stops and aspiration in final and medial position, the variation in vowel length, the distribution of velars, the distribution of diphthongs, and the relationships between $/ w /$ and $/ u /, \cdot / y /$ and $/ i /$, and $/ f /$ and /w/. These may be clarified when the morphemic analysis is complete. The phonemic system appears to resemble most closely that of the neighboring Molala, although the lexicon and grammar show only slight similarities; the related Takelma also seems quite similar phonologically. 
Since phonological features can be borrowed by one language from another, and in the Northwest frequently have been, further examination of such resemblances may shed light on former historical contacts between Kalapuyan speakers and other groups. 
MARY'S RIVER KALAPUYAN :

A DESCRIPTIVE PHONOLOGY

by

Yvonne P. Hajda

A thesis submitted in partial fulfillment of the requirements for the degree of

MASTER OF ARTS

in

ANTHROPOLOGY

Portland State University

1976 


\section{ACKNNOWLEDGEMENTS}

I would like to thank the members of my thesis committee--Wayne Suttles, Joe Pierce, and David French--for their help and patience.

The Melville and Elizabeth Jacobs Research Fund, Whatcom Museum Foundation, kindly provided a small grant which facilitated access to the Melville Jacobs Collection at the University of Washington.

Special thanks are due to Henry Zenk, whose interest in and knowledge of things Kalapuyan stimulated and maintained my own interest and greatly contributed to my knowledge; and to Susan McClure, whose linguistic expertise and interest in Santiam Kalapuyan morphology have saved me from some egregious errors. This thesis would not have been completed without their help, encouragement, and senses of humor. 
TABLE OF CONTENTS

PAGE

ACKNOWLEDGEMENTS

iii

CHAPTER

I INTRODUCTION

II ANALYSIS OF DATA .....................

III SUMMARY AND CONCLUSIONS $\ldots \ldots \ldots \ldots \ldots \ldots \ldots \ldots$ 
CHAPTER I

INTRODUCTION

\section{Kalapuyan and Its Classification}

The three Kalapuyan languages were formerly spoken in the Willamette Valley of Oregon. The last known speaker, John Hudson, who served as an informant for the Santiam dialect, died sometime in the 1960's. The northern language included two known dialects, Tualatin and Yamhill; the central language consisted of some undetermined number of dialects, including the two best documented, Mary's River and Santiam; the southern, Yoncalla, is known only in one dialect, but apparently included others (Jacobs 1930:4a). These three languages appear to have been mutuallv unintelligible. Jacobs $(1930: 4)$ says "they [the Kalapuya] sav that thev form three dialect groups, one of which does not understand the other readily, though it be possible to learn to understand and express oneself in the adjacent dialect within some weeks."

In the Powell classification of 1885-86 (Powell 1891), Kalapuyan is treated as a language family, while another Oregon language, Takelma, now considered by many to be related, is treated as a language isolate. Kalapuyan is included, together with Takelma and Coast Oregon Penutian (Coosan, Siuslawan, and Yakonan), in Sapir's "Oregon Penutian" (1921, 1929), one of six branches of his proposed Penutian stock. The other five were California Penutian, Chinookan, Tsimshian, Plateau Penutian, and Mexican Penutian. "California Penutian" was the term proposed by Dixor and Kroeber (1919) for a group of related California languages; 
these are sometimes referred to as the Penutian core. In one sense, "Penutian" includes any language or language family that can be shown (or is thought) to be related to California Penutian.

In 1918, Frachtenberg suggested a probable common origin for Coosan, Siuslawan, Yakonan, and Kalapuyan, and the relationship of these, together with Takelma and Chinookan, to California Penutian. He refers to Takelma, the Coastal languages, and Kalapuyan as "Oregon Penutian" (1018:176-177). Three years later, Sapir quotes Frachtenberg's grouping and says that he had independently arrived at the same classification. He agrees with Frachtenberg that Coosan and Siuslawan are "divergent representatives of a single linguistic stock" and says that Coosan and Takelma are clearly related; they and Siuslawan have an "astonishing number" of lexical and morphological correspondences (1921:58). He feels Frachtenberg is much too cautious about connecting Chinookan to Penutian (though he points out that half of Frachtenberg's nineteen possible Chinook-Kalapuya cognates are borrowings from Chinook), thinks the Takelma-Kalapuyan relations are genuine, and includes Tsimshian as Penutian (1921:59). His "provisional scheme" showing the internal relationships of Oregon Penutian $(1921: 60)$ is the same as that presented in 1929 (though for Penutian as a whole, the 1921 grouping does not include Plateau Penutian and Mexican Penutian, which were added later).

Frachtenberg presented a list of 53 possible cognates to support his suggestion that Kalapuyan and Takelma were closely related; he mentioned some of the common "phonetic shifts" and morphological similarities, but he was cautious in suggesting an ultimate relationship, saying there were great structural differences (1918). In 1965, Swadesh presented more evidence of the Kalapuyan-Takelma relationship; he had 
earlier grouped them together as the "Takelman" family (1956). He estimated a time depth of 2400 years' divergence for Takelman, and 1200 years for Kalapuyan (1965:237); earlier (1956:21, 41) he estimated 4400 years for Takelman and 9000 years for Penutian as a whole. Shipley has attempted phonemic reconstructions of proto-Kalapuyan (1970) and protoTakelman (1969). "Takelman" seems to be acceptably real. As late as the AES map of 1966, however, Voegelin still shows Takelma as a language isolate (also 1964:119).

Relations among the other Oregon Penutian languages remain unclear. Pierce has suggested (1965, 1966) that the languages may be less closely related than had been assumed, or in some cases may not be related at all: e.g., the two Coosan languages, Hanis and Miluk, may resemble each other because of convergence rather than common ancestry. Aoki, however, suggests that the differences may be due to Athapaskan influence on Miluk, and Silverstein says that the differences may be mainly in surface arrangements of similar elements (Thompson 1973:992-993). "Yakonan" no longer includes Siuslawan together with Alsea and Yaquina, but Aoki (Thompson 1973:994) feels that on the basis of lexical sets Siuslawan is closer to Alsea than it is to Coosan; Thompson suggests that the three should be considered as coordinate groups. "Oregon Penutian" mav be - only a geographical distinction, not a linguistic one.

Shipley has suggested that Kalapuyan may be more closely related to Miwok-Costanoan (California Penutian) than it is to the other Oregon Penutian languages (1970). He and others have pointed out the relative lack of glottalization in Kalapuyan, as compared with Chinookan and other Northwest languages, creating a mellifluous effect. Gatschet writes that the language is "sonorous, sweet, soft, and vocalic" 
(1877:153); Jacobs called it "one of the most beautiful languages I have heard in my linguistic experience," as compared to the "fatiguing and execrable rasp, splutter and. cacophony of Chinook, Molale, Sahaptin and Salish" (1930:n.p.). Early settlers and travelers made similar observations-Jesse Applegate, for instance, remarks that "their language was remarkably smooth and musical" (1930:178).

Much comparative work and imaginative speculation have been produced to support Sapir's hypothesis and to extend it. Hymes suggests three stages in the development of the Penutian hypothesis: (1) the Dixon-Kroeber' classification of California languages (1919), (2) Sapir's addition of other Pacific Coast languages (1921, 1929), and (3) the extension of Penutian by Freeland, Sapir, Whorf, Swadesh and others to include various additional native languages of Latin America (Hvmes 1959: 69). The latter stage is mostly post-World War II. The trend-in Penutian work has been to include, not exclude, languages and language families. In 1958, Pitkin and Shipley say, "Penutian investigations have followed a pattern of supplying to the literature new and bold, but undemonstrated, hypotheses of wider and wider relationships, while those suggestions already in the literature have stood uninvestigated for the last half century" (Pitkin and Shipley 1958:175). In 1966, Shipley attempted to remedy this by showing the relationship of Klamath to the California core. Also in 1966, Rigsby showed that Cayuse and Molala, the former "Waillatpuan" family, are not related at the family level, but Molala is probably still Plateau Penutian. Sapir's Penutian appears to be largely accepted as a linguistic fact (e.g., Hymes 1964), though the parts are rearranged from time to time. But Thompson's statement is still accurate: "The groupings of the putative northem extension of 
California Penutian are still in question--indeed the relation of many of the languages remains not yet established, for some not even proven" $(1973: 987)$.

It is not my purpose here to explore these larger connections further, but only to establish the phonemic system of one dialect of Kalapuyan. I hope this will help to provide slightly more secure footing for the Penutian expedition.

\section{Resources}

A considerable amount of phonetically transcribed material exists, particularly for the northern and central languages. Some early vocabulary lists were collected: the Rev. Samuel Parker collected some forms from a central dialect in the 1830's (Parker 1838:333-336); this may be the earliest such list, but at about the same time, Dr. Tolmie transcribed words from what is probably Tualatin (Scouler 1841; cited in Powe11 1891:81). In the early 1830's, Hale of the Wilkes Expedition collected vocabulary from a number of Indian groups, including some from two probably Tualatin-speaking informants (Hale 1846:564-629). Gibbs (1851) has a Yamhill vocabulary from two signers of the Champoeg Treaty. There is also a list of forms from a central dialect from Barnhardt in 1859. None of these lists is phonetically reliable; Hale's is undoubtedIy the best.

In 1877, Albert S. Gatschet made the first substantial contribution to the 1 inguistic knowledge of Kalapuyan. He had already begun work on other American Indian languages, which was to continue; he and Dorsey were the major contributors to the work of the Powell classification (Sturtevant 1959:196-199). Before coming to America, he had made con- 
tributions to the study of European languages as well. In his Kalapuyan work, he concentrated mostly on Tualatin, recording vocabulary, grammar, ethnographic and historical texts from Peter Kenoyer and Dave Yatchkawa at the Grand Ronde Reservation, collecting partial Luckiamute and Ahantchyuk (central dialects) vocabularies, using Powell's outline, and a Yamhill vocabulary from Peter Selky, also at Grand Ronde. He stressed the importance of using only a "scientific" alphabet, that is, one.which uses the same letter for the same sound (1877a:148), advice which he did not follow himself: [ $¥$ ] is usually "thl" in his manuscripts, for instance. He is not as accurate as later linguists, having missed glottalization and some other distinctions, but his work is nevertheless quite usable. His manuscripts are in the National Anthropological Archives.

In 1913-14, at the Siletz Agency and at Chemawa, Leo J. Frachtenberg recorded thirteen manuscript volumes of myth texts in the central Mary's River dialect. (He had worked with other Westem Oregon Ianguages previously.) Something over one volume of the texts are from Grace Wheeler, the rest from William Hartless.' Jacobs refers to Wheeler's "Lower McKenzie River dialect" (1945:351), but Frachtenberg says "Grace Wheeler is a Kalapuya, Wm. Hartless is a Mary'sville. Both dialects the same, but traditions different according to Grace" (1913-14a, Vo1. 3, n.p.). There are three volumes of notes to the texts (1913-14b), and three volumes of grammatical notes (1913-14c). The latter are largely from Hartless, with some material from Grace Wheeler, apparently corrected with Hartless. There is a collection of ethnographic notes from Hartless (1913a). From other dialects, Frachtenberg collected vocabulary, grammatical notes and a short text in Yamhill, from Louise Selky, and 
Yoncalla vocabulary and grammatical notes from Mrs. Robert Allen and Mrs. Tom Jackson, collected at Grand Ronde (1913b, 1914). In 1915, Frachtenberg made marginal notes and corrections directlv in Gatschet's field notebooks of Tualatin with the help of Louis Kenoyer (Peter Kenoyer's son and the last known speaker of Tualatin) at the Yakima Reservation. He completed some typescripts of his own and Gatschet's texts in which he normalized his own transcriptions to some extent. The original manuscripts of his field notebooks and some other materials are to be found in the National Anthropological Archives; his slip files, some typescripts, and some other materials are in the Jacobs Archives; and some typescripts, which I have not seen, are apparently also in the American Philosophical Society.

Frachtenberg does not list the symbols used in his Kalapuyan manuscripts or their values anywhere, but it is not difficult to figure them out. In discussing the similarities and differences of Kalapuyan and Takelma phonology (1918:179), he gives a few symbols and describes their phonetic values. He does present such lists of symbols for his earlier work in Coos, Siuslaw, etc. (1922a, 1922b), and these, together with the Smithsonian guide (Boas, et al. 1916) and general familiarity with the symbols used by Boas and his students at the time, make it possible to be reasonably certain of the values intended. Frachtenberg's materials are more reliable than Gatschet's, but Jacobs, for one, mistrusted his phonetic abilities (1945:204). Jacobs does say that the Mary's River texts are probably Frachtenberg's best work (which fact he attributes to Hartless' excellence as an informant). Hymes has also poiñted out some of Frachtenberg's inconsistencies and limitations as a phonetician in his work with Siuslaw (1966:328-342). 
Melville Jacobs collected material largely in Santiam, from Eustace Howard at West Linn, and John Hudson at Grand Ronde, during 1928-36. He had done a considerable amount of work with other Northwest languages, perhaps more Sahaptin than anything else. He checked and corrected some of Gatschet's and Frachtenberg's materials with John Hudson and Louis Kenoyer. He also collected some Yoncalla vocabulary and did further work on Tualatin with Louis Kenoyer. He published most of Gatschet's Tualatin texts and Frachtenberg's Mary's River texts, after reworking them in his own phonetic transcription (that of the Smithsonian guide) and correcting them with the help of John Hudson and Louis Kenoyer, together with much of his own material from Hudson (Jacobs 1945). Further, he recorded some material from Hudson on Edison wax cylinders; fortunately this is now on tape, but the sound quality is still that of the much-played originals. Jacobs started work on a grammatical sketch of Kalapuyan, which was not published (1930); and there are notes on the phonology and grammar in the introductory sections of the published texts and in an unpublished autobiography of Louis Kenoyer (n.d.). Jacobs' materials are probably the most phonetically reliable, but even so they suffer from some confusion of morphophonemic, phonemic, and phonetic information, as Lisker (1946) has pointed out, making for some uncertainties in reconstructing the phonological system. His unpub1ished materials are in the Jacobs Archives.

Jaime De Angulo and L. S. Freeland began an unpublished grammatical sketch of Tualatin, collected texts from Louis Kenoyer in 1928, and began -the autobiographical sketch of Kenoyer, continued later by Jacobs. Their materials are in the Jacobs Archives and at the American Philosophical Society. 
Morris Swadesh was the 1ast Iinguist to work with John Hudson, collecting some vocabulary from him in 1953. A tape of good quality exists, on which a word list and a brief text is recorded. The tape is in the Languages of the World Archives at Indiana University. Some of Swadesh's materials were published in his 1965 article.

No complete analysis of Kalapuyan phonology exists. The valuable uncompleted analysis by Jacobs has been mentioned. Frachtenberg has occasional comments scattered through his texts, notes, etc., but while these are useful in pointing to things needing investigation, they have not proved very helpful in analysis.

In comparing Kalapuyan to Takelma, Swadesh (1954), using a phonemic transcription but presenting no phonemic analysis, gives a list of cognates in the three Kalapuyan languages. Shipley (1969, 1970) presents his own proto-Kalapuyan reconstruction, apparently based largely on Swadesh's word lists. And in a critical review of Jacobs' Kalapuya Texts, Lisker (1946) presents a list of Santiam phonemes, with no indication as to how he arrived at them.

\section{Problem and Method}

The material I have analyzed here was selected somewhat arbitrari1y. Mary's River was chosen in the first place because of the sizable amount of material available--next to Santian, it is probably the bestdocumented Kalapuyan dialect. Santiam is much better known, because of the Jacøbs texts; this made Mary's River more interesting to me. I started with the first six myth texts in the manuscripts of Frachtenberg's Mary's River texts; this takes up the first two volumes, and seemed to be more than adequate material to work with. I supplemented this with 
terms from the ethnology and (cautiously, since it is not always clear who the informant is) by the grammatical notes. (I have had access to Xeroxed copies of all of these, obtained from the National Anthropological Archives.) The six myths are titled "Coyote and the Gamblers," "Coyote and Panther," "Grizzly and Panther," "Coyote's Adventures," "Coyote as Culture Hero," and "The Boy in the Moon." Under somewhat different titles, they appear as Mary's River myths numbers 1, 2, 8, 5 , 3, and 9 in the Jacobs texts (1945). Thanks to the Jacobs Archives, I have been able to look at a typescript of the fifth myth, "Coyote as Culture Hero," prepared by Frachtenberg from his manuscript. I have consulted the tapes of Hudson (though these are in another dialect) for evidence especially on the accentual system, and I have examined Jacobs ${ }^{\top}$ reworking of Frachtenberg's texts.

I have used the Jacobs versions (and the tapes) only to provide clues to interpretation, however. Jacobs says that Frachtenberg's recordings from Hartless were "in such excellent condition as to allow consistent standardization and accurate checking," so that he needed only to eliminate obvious inconsistencies and errors (1945:204). These involve, he says, failure to recognize an "intermediate" series of consonants, inconsistency in recording glottal stops and glottalized consonants, lengthening of some vowels and diphthongs, treating many morphemic elements as separate words which were not separated in normal speech, and treating $/ \mathrm{k} /$ and $/ \mathrm{g} /+\mid \mathrm{y} /$ as palatalized stops instead of as sequences of stop plus /y/ (1945:146-147). But Jacobs himself never writes $/ \mathrm{ky} /$, only $/ \mathrm{k} /$; and Frachtenberg removes all palatalization marks in his typescript. (Some of these "errors" will be discussed at greater 
length in: Chapter II.) He does not explain how Hudson, speaking a different though closely-related dialect, was able to provide a check on Mary's River pronunciation. Jacobs' remarks about Frachtenberg's similar "corrections" of Grace Wheeler's speech by William Hartless apply to himself as well:

I have not always been able to disentangle the linguistic changes, from a Lower McKenzie River original, for which Mr. Hartless may have been first responsible. As consequence, the Wheeler dictation may be somewhat covered by a Hartless overlay in Mary's River dialect. Add to that the Hudson superimposition in Santiam dialect, for which I am responsible, and the student is confronted with a stratification through which it may be often difficult to determine what is pure Lower McKenzie (1945:351).

To determine Mary's River phonology, therefore, it seems better to rely primarily on Frachtenberg's own recordings.

What I have attempted to do here is to present as complete an analysis as possible of the "taxonomic" phonemic system of the Mary's River dialect, using standard descriptivist techniques (as presented in, e.g., Gleas on 1961:257-341 or Pike 1963). There are obvious difficulties in basing such an analysis on the sorts of material available, and these will become more obvious as the analysis proceeds.

Most descriptive phonemic analyses are based on fieldwork with informants. Here, I am using phonetic transcriptions which can no longer be checked against actual speech. I must of necessity rely on Frachtenberg's accuracy, or try to discover what inaccuracies did exist. I have assumed that his symbols represent phonetic realities, and I have-followed his indication of "word" boundaries, although often' the forms that are written with spaces on either side may be morphemes separated in slow speech, as Jacobs claims, rather than independent forms. Frachtenberg's transcriptions of a form often do appear to vary 
considerably. For instance, a word he translated as "now, then" appears in some five slightly different forms. These could be due to mishearings by Frachtenberg, to variations in speech by Hartless, or perhaps to the lumping of morphologically different but phonetically similar forms under one translation. One variant, $1 \mathrm{a}^{\mathrm{u} ?}{ }^{2}$ is by far the most frequent, occurring 87 times in the six myth texts. The others in the texts are $\underline{\text { lau }}$ (twice) and $\underline{1 \cdot a u^{?}}$ (twice); $\underline{1 \text { aú }}$ (once) and $\underline{1 a^{\mathfrak{u}}}$ (once) occur in the grammatical notes. It would appear at least that $1 \mathrm{a}^{\mathrm{u}}$ can be relied on as the modal form, whatever accounts for the others. In some cases, one finds two or three variants occurring equally often in the manuscripts. These I have taken to be phonemic or phonetic variation on the part of the informant (as the others may also be, of course) rather than recorder error.

Some variations are fairly easy to attribute to Frachtenberg's difficulty in distinguishing sounds. $\underline{k}$ and $q$, for instance, are often written over each other, as well as appearing to vary freely in representations of the same form. nak "say, said," for instance, is often written over naq in the first four pages of the first myth (see Appendix for an example), but Frachtenberg finally settles on nak. In spite of

Frachtenberg's interlinear translations are very rough. My glosses are based on these translations, and are not to be taken as exact identifications.

${ }^{2}$ I have underlined symbols and forms used by Frachtenberg in his manuscripts, and used the conventional brackets and slash marks to indicate phonetic and phonemic values, where necessary. In citing Frachtenberg's forms, I have used his symbols, except that I write p (etc.) for $p !, ?$ for $\varepsilon, o^{\cdot}$ (etc.) for $\underline{\delta}$. I have typed a instead of writing $\underline{a}$. I have generaliy enclosed in parentheses those symbols which are used in some variants of a form but not in others, to avoid listing all variants: e.g., má.pa(?)t(5) includes má.pat (3) and ma.pa?t (2). 
the inconsistencies, some environmental conditioning of $\underline{k}$ and $\underline{q}$ is in fact evident--not enough, however, to say that $\underline{k}$ and $q$ are clearly in complementary distribution. Because of the "free variation" (on. Frachtenberg's part), and supplemented by the trend to conditioning, $\underline{k}$ and $q$ have to be treated as members of one phoneme. Jacobs agrees, and is explicit about the variation (1930:n.p.).

Establishing the range of variation has been the most difficult methodological problem. My procedure has been first to tally the number of times each variant of a form occurs, as in the example of $1 \mathrm{a}^{\mathrm{u}}$ ? This has produced a list of forms ranging from a considerable number of single examples of forms, to some which occur many hundréds of times--e.g., the verbal particle written $\mathrm{k}^{\mathrm{u}} \mathrm{m}$ (493 occurrences) or kum (116 occurrences). Some of these vary not at all, but some have up to twenty or thirty different forms. Most of the variation lies in the omission or addition of vowel length, aspiration, or glottalization; vowel quality differences account for most of the rest.

By taking the variants which occurred most frequently, I was able to establish modal forms in a considerable number of cases, though sometimes my decisions were arbitrary ones. Working first with these modal forms, I examined the distribution of sounds in the usual way to try to establish contrast and complementary distribution. To check emerging patterns, I examined single examples and those cases where the variation did not yield clear-cut modal forms. For instance, píinnE /girl" occurs 26 times, with differences in the final vowel twice; p’íne "have, keep" occurs five times, with differences in the final vowel. This appears to reveal a contrast between initial $\mathfrak{p}$ and $p$. Initial $\mathfrak{p}$ occurs much less 


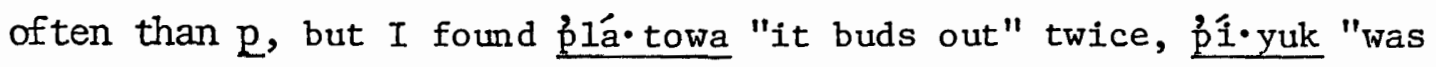

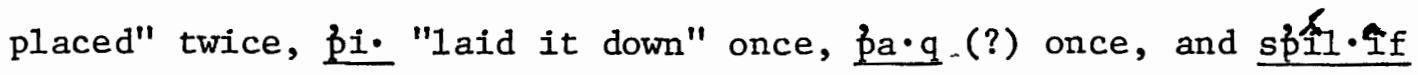
"little bugs" once. I also found two forms varying in initial stop: pá.s(E) la?t occurred three times (and pá.sau "smoke!" once) and the same with unglottalized p occurred once ("smoking"); and also p’áslau? eight times, páslau? five times ("enough, let's quit") also occurred. (Initial $p$ occurs in the same environments as all of these.) I took the two variable forms to contain /ṕ/. (though ṕáslau? at least is uncertain). Another instance of $\underline{\mathrm{p}} \sim \underline{\underline{p}}$ is $\underline{\text { pau? }}$ (three times) and pau? (20 times) ("canoe"); I took these to contain $/ \mathrm{p} /$.

For some sounds, no or very few modal forms could be established, or the variation was so great that instances of contrast could not be cited with any confidence. Forms containing final $\underline{{ }^{t}}$ or $\underline{t}$ were of this kind: for example, the suffix -tnt (11 times), th?t (13 times). Most forms varied in this way, though $\underline{2 t}$ is more common than $\underline{t}$ in final position. As already noted, forms with $\underline{k}$ and $\underline{q}$ vary in this wav: and so, especially, do those with vowels--e.g., a form "they kept going" shows

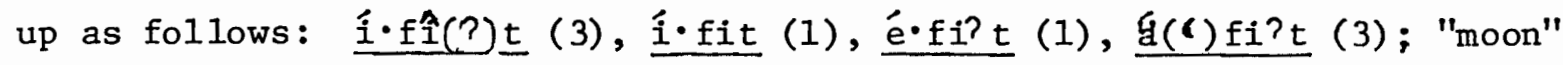
occurs as tó.pi+?. (3) and tú.pi・? (2).

There was no unarbitrary way to rely on statistical tallies to establish the existence of free variation, contrast, or complementary distribution. For instance, al though [0] can be established as modal in a few forms (e.g., pínE for "gir1," with two variant forms, píni and píne(), there is no instance except for single examples in which [o] does not vary with some other vowel or with nothing. This led me to examine its distribution more carefully, and eventually I decided that [ə] 
was non-phonemic (see Chapter II). Patterning, as well as numerical distributions, has to be considered in any phonemic analvsis.

Errors in my analysis may have a variety of sources: insufficient examples of forms, errors in Frachtenberg's recording, Hartless' mistakes in speaking, my mistakes in analysis, and so on. A further source of possible error, however, lies in the fact that a morphemic analvsis of Kalapuyan has not yet been completed. Since the identification of morphemes is therefore not always as secure as it might be, some phonemic variation may have been taken as phonetic variation, and vice versa. Although I have sorted out some morphophonemic variation, an intractable residue remains. 
CHAPTER II

ANALYSIS OF DATA

The problem I have set myself is to reduce Frachtenberg's numerous phonetic symbols to phonemes. His symbols are arranged in the following chart according to the phonetic values they probably represent (see discussion of the interpretation of Frachtenberg's svmbols in Chapter I). Since some of his symbols are no longer in common use, I have added my own equivalents in brackets.

\section{Consonant Symbols}

Stops Affricates Fricatives Nasals Laterals,

$\underline{\text { Labial }}$

Voiced b

Voiceless p

$\mathrm{m}, \mathrm{m}[\mathrm{m}]$

$\mathrm{w}, \mathrm{w}[\mathrm{u}]$

Aspirated pr

Glottalized $\mathrm{p}:[\mathrm{p}] ; \mathrm{p}^{\prime}$

Alveo-dental,

Alveo-palatal

Voiced d

Voiceless

$t, \bar{t}[t \cdot]^{\cdot}$ ts, $t c[t \check{s}]$.

$s, \bar{s}[s \cdot]$,

Aspirated $t^{c}$

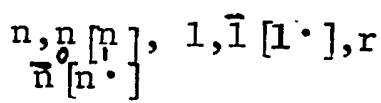

$L\left[\frac{1}{0}\right]$

$c[\tilde{s}$ ]

Glottalized $t:[t], t^{\prime} t s !\left[t_{s}\right]$,

$\underline{\text { Palatal (ized) }}$ tc! [ts ]

Voiced

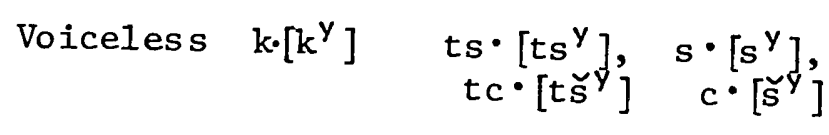


Velar Stops Affricates Fricatives Nasals Laterals, Voiced $g(?)$

"Voiceless k $\mathbf{x}$ Aspirated $\mathrm{k}^{\mathrm{r}}$

Glottalized k! [k].

Labialized $\mathrm{kw}, \mathrm{k}^{\mathrm{u}}$

Back Velar

Voiceless q

Glottalized q! [q́].

Labialized qw, $q^{\mathrm{u}}$

$\underline{\text { Glottal }} \&[?] \quad h, c$

Vowe1 Symbols

Unrounded Front Rounded $\cdot \underline{\text { Center }} . \quad$ Back

High $i, \underline{I}[i \cdot]$

\begin{tabular}{|c|c|c|}
\hline \multicolumn{3}{|c|}{$u, \bar{u}\left[u^{\bullet}\right]$} \\
\hline & $\hat{1}[\dot{z}]$ & $\stackrel{\circ}{\mathrm{u}}[?], \mathrm{u}[? v]$ \\
\hline$\ddot{o}$ & $E[\partial], E\left[\partial^{\bullet}\right]$ & $\circ, \bar{o}[0 \cdot]$ \\
\hline & & $\widehat{o}[\Omega]$ \\
\hline
\end{tabular}

Low

$\hat{a} \quad \hat{w}[0]$

$a, \bar{a}[a \cdot]$

$a^{i}\left[a_{i}\right], a_{i}\left[a_{i}^{i}\right], a^{\bar{i}}\left[a_{i} \cdot\right], a_{i}\left[a_{i} \cdot\right]$

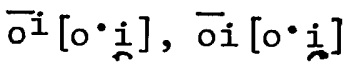

$a^{\mathrm{u}}\left[\mathrm{aun}_{\mathrm{n}}\right], a \mathrm{u}\left[\mathrm{aun}_{\mathrm{n}}\right], \mathrm{a}^{\overline{\mathrm{u}}}[\mathrm{au} \cdot], a \overline{\mathrm{u}}\left[a \mathrm{u} \cdot{ }^{\prime}\right.$

Generally the second elements of $[a i \cdot]$ and [au•], and the first of $[0 \cdot i]$ are shown long, but sometimes the lengthening is reversed, or both are rarked 1ong. 
Comments on Symbols

Frachtenberg uses a raised dot following a consonant to indicate palatalization (k., etc.). In the typescript of the fifth myth, Frachtenberg removes all palatalization marks. In his slip files, Frachtenberg uses the later half-circle under a consonant ( $k$, etc.) for the raised dot of the manuscripts; but some forms containing palatalized symbols in the manuscripts do not show palatalization in the slip files, and vice versa. Length of consonants and vowels is indicated by a macron ( $\bar{s}, \bar{o}$, etc.). The circumflex over vowels indicates a short vowel; in most cases it probably also meant a somewhat lowered tongue height. The vowel qualities intended by Frachtenberg are somewhat more difficult to establish than consonant qualities; short unstressed vowels are a special problem, since they seem to represent central vowels on occasion, as well as their primary values.

The segmental phonemes probably were organized so as to utilize certain of the phonetic features, in the following way:

\section{Probable Segmental Phonemes}

\section{Consonants}

Plain Glottalized

Labial

$$
\mathrm{p}
$$

$\dot{\mathrm{p}}$

$\mathrm{f}$

m

$\mathrm{w}$

$\begin{array}{llllll}\begin{array}{lll}\text { Alveo-dental, } \\ \text { Alveo-palatal }\end{array} & t & t & s & n & y \\ \text { Velar } & c & c & t & 1 & \\ \text { Labiovelar } & k & k & x & \\ \text { Glottal } & k^{w} & k^{w} & & \end{array}$


Vowe1s
Diphthongs
Front Center Back
High $i \quad i$
Low
$\mathrm{u} \mathrm{u}^{\bullet}$
a $a$
Low
ai
ui
$a u \quad a \cdot u$

\section{Inventory of Phonemes}

\section{Consonants}

/p/ initial, medial, final. ${ }^{1}$

[b] (b) ${ }^{2}$ occasional after $/ \mathrm{m} /$; sometimes varies freely with [p]. tcámbek• (16) tcámplak• (1) "chief"3 mábat (1) ma.pa(?)t (5) "still, yet"

[P] (p) elsewhere.

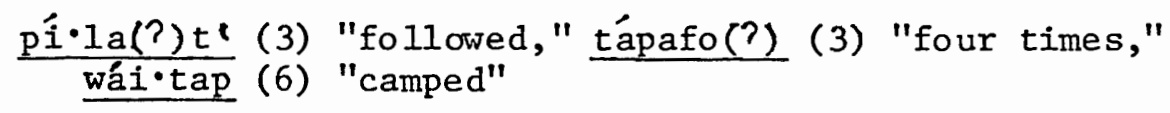

Contrast: /f/ $\mathrm{pa}$ (11) "then, in that case," $\mathrm{fa}$ ? (3) "foot" $/ \mathrm{w} / \frac{\mathrm{pa} ?}{\mathrm{pa}}$ (11) "then, in that case," $\frac{\mathrm{wa}}{\mathrm{wa}}$ (102) "no, not"

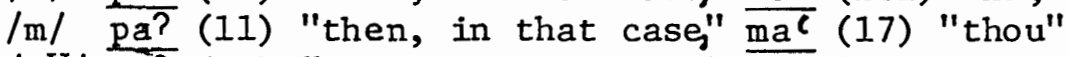
$/ \mathrm{k}^{\mathrm{W}} / \mathrm{pa?}$ : (11) "then, in that case," kwa(1) (5) "took it" $/ \mathrm{p} /$ pi-nE (24) "girl," pínE(?) (5) "have, keep"

/t/ initial, medial, final.

[d] (d) occasional after $/ \mathrm{n} /$; sometimes varies freely with [ $\mathrm{t}]$.

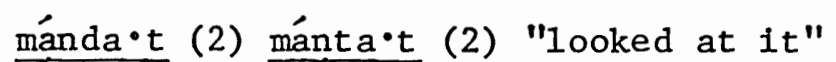
dukulhu? (1) tukulhu? (1) "ow1"

1

Because morpheme boundaries are not always known, the environments are word-initial, medial, final, unless otherwise specified.

${ }^{2}$ Frachtenberg's symbols, underlined and enclosed in parentheses, follow the allophones they represent.

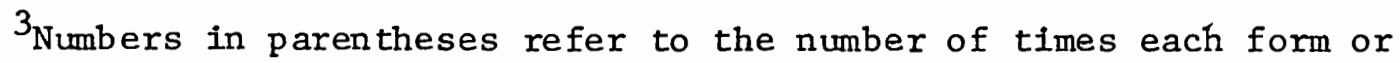
variant occurred. If only one form is cited, it is the modal form. In the forms, symbols in parentheses are variable; I have 1isted all vari-. ants in full only when relevant to the particular example. See note on page 12 for my normalization of Frachtenberg's transcriptions. 
[t] (t) elsewhere.

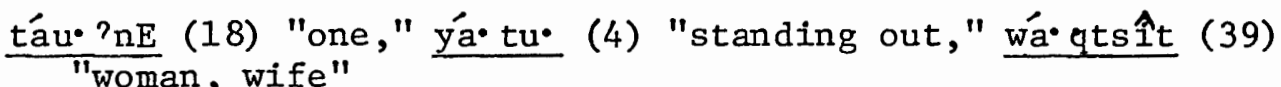

Contrast: /c/ th? (7) "tooth," tc $(\cdot)$ ㄹ? (8) "I"

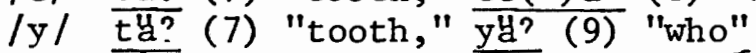

/n/ ta(?)kal(?) (2) "fir bark," náka(?)t(c) (12) "said"

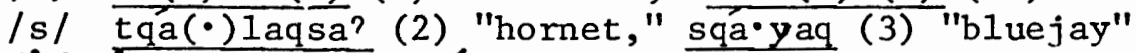

$\mid t /$ Eau (3) "ee1," tau•?nE (18) "one"

/c/ initial, medial, final.

$\left[t s^{y}\right]\left(t s^{\bullet}\right),\left[t Y^{y}\right](t c \cdot)$ vary freely with each other and with [ts] and [ts]; somewhat more frequent before or after feont vowels.

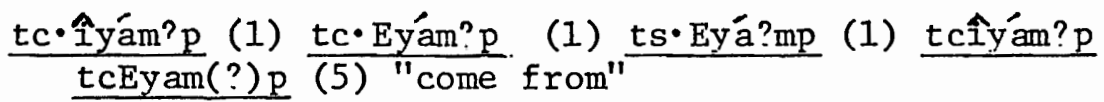

$[t s](\underline{t s}),[t \tilde{s}](\underline{t c})$ elsewhere.

tcá·po? (2) tsá.po? (1) "basket," mî.

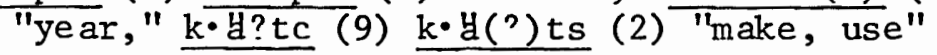

Contrast: see /t/

/s/ tco' (14) "where," so(') (10) "good"

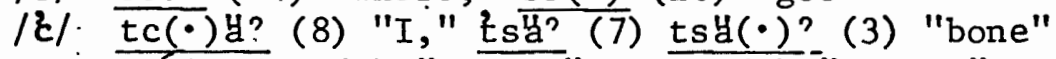
tsalfafo? (1) "noise," tsa?1 (5) "river;" Esálaftsálaf (2) "bee beetle, horned toad"

/k/ initial, medial, final.

$\left[k^{y}\right]\left(k_{\bullet}\right)$ varies with $[k]$; more frequent before or after front vowels.

k•i. (31) ki• (1) "if, when"

[q] (q) before. $[0],[a],\left[a^{\cdot}\right],\left[a u,,\left[0 \cdot{ }_{n}^{i}\right]\right.$; varies with $[k]$.

qó·tqai (24) kó•tkai, (1) "woke up, got up," wáqa? (4) wáka?

"slave," sqolq (2) sqolk (1) "went in a circle"

[k] (k) elsewhere; rare before $[0],[a \cdot])$.

kam (36) "they, he, you will," yíckun (8) "maybe," tmúak (12) "salmon"

Contrast: / $\mathrm{kw} / \mathrm{kin}$ (14) "went (?), " $\mathrm{k}^{\mathrm{w} \text { in }}$ (19) "got hold of, took" $|x|$ Ea.gta(?)t (2) "tied it," tóxta·t? (1) "I knock;"

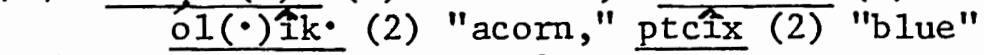
/h/ ka (4) "your (?)," ha? (11) "up; voice, mouth" 
/?/ wo ? k (58) "arrived,"wo•? (4) "go back after" $\mid \vec{k} /: \frac{\mathrm{ku} \cdot t k u m u}{\text { of } m e^{\|}}$(6) "morning," $\underline{k u \cdot p t a t c a ? f}$ (3) "make fun

$/ \mathrm{k}^{\mathrm{W}} /$ initial, medial; not found before [o] or [u].

[qu] (qw) varies with [ku] .

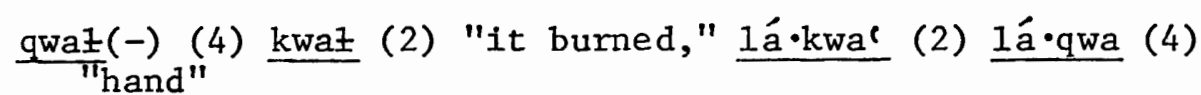

$[\mathrm{ku}]$ (

kwíle $(\cdot) k \cdot$ (9) "eye,"

Contrast: see $/ \mathrm{k} /$

/w/ wa? (102) "no, not," $\mathrm{q}^{\mathrm{w}_{\mathrm{a}}(\zeta)}$ (5) $\mathrm{k}_{\mathrm{a}}$ (3) "head, hair" $/ \mathbb{k}^{\mathrm{w}} ! \frac{\mathrm{q}^{\mathrm{w}}(\mathrm{c})}{\text { was }}$ pregnant" $\mathrm{kwa}^{\mathrm{w}}$ (3) "head, hair, "kwayayu. (1) "she

/p/: initial.

[p] (p!)

p’íyuk (2) "was placed," plé·towa(') (2) "it buds out"

Contrast: see /p/

$|t|$ ịnitial.

[t]: (t!)

$\underline{t_{a u}}$ (3) "eel," $\underline{t_{w a t t E n i}(?)}$ (3) "he poked it"

Contrast: see / $t /$.

$\mid \grave{c} /$ : initial.

[t́s] (ts!), [ť́š (tc!) free variants.

Es la? (4) Éšla(?) (2) "anus, inside," t́sálaft́salaf (2) "bee beetle, horned toad"

Contrast: see /c/

$\mid \vec{k} /$ initial.

[q] ] (q !) varies with $[\vec{k}]$.

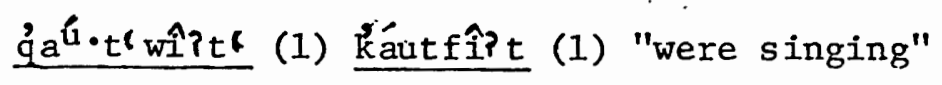

$[k]$ : (k!) elsewhere. 


\section{kálha(·)pkwa(') (3) "she peeped in"}

Contrast: see $/ k /$

$/ \mathrm{k}^{\mathrm{W}} /$ initịal.

([qua (q!w) occurs once as a variant of [qu ].)

[ku $](\underline{k ! w})$

k̉wáyayu• (1) "she was pregnant," kwaíhen (1) "chewed up" (All other instances of $\underline{k w}$ vary with $\underline{k w}$ or with $\underline{q w} \cdot$ )

Contrast: see $/ \mathrm{k}^{\mathrm{w}} /$

$/ ? /$ inferred to exist in syllable-initial prevocalic position; syllablefinal, postvocalic.

[P] $(\underline{E})$

$$
\text { wa? (102) "no, not" }
$$

Contrast: /h/ fa? (4) "foot," yas (5) "did"

$$
\text { see } / \overline{\mathrm{wa}} / \mathrm{k} \text { la? (2) "nowhere, " wálac (22) wála (6) "downhill" }
$$

/f/ initial, medial, final.

[尹] ( $\underline{\text { f }}$

$\underline{f^{\prime} \cdot f_{u f l a} \cdot t a ?}$ (1) "cooking basket," póntcu·f (5) "make you"

Contrast: /h/ fa?.(4) "foot," ha? (11) "up; voice, mouth" see $/ \mathrm{p} / \mathrm{fo \cdot i?ya}$ (1) "put on clothes," xoí-wai (1) "drunk"

/s/ initial, medial, final.

$\left[s^{y}\right]\left(\underline{\left.s^{\bullet}\right)},\left[\tilde{s}^{y}\right](\underline{c} \cdot)\right.$ vary freely with each other and with $[s],[\check{s}]$; somewhat more compon before and after front vowels.

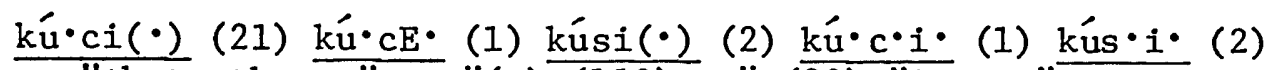
"that, there," s.nht(c) (110) snu (29) "Coyote"

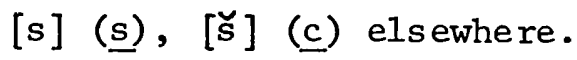

cápli (1) sápli (1) "bread," wa.úso?. (10) "nobody," wí·nas (20) "indeed," kuc (100) kus (1) kuc- (1) kus. (1) "that, there"

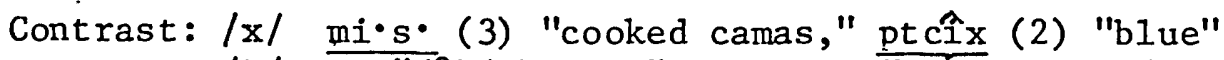

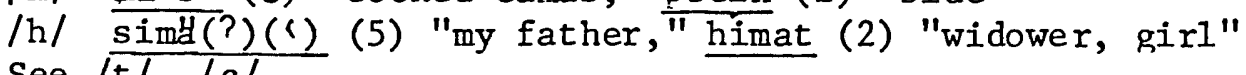
See $|t /| c \mid$, 
II/ initial, medial, final.

$[\exists](\underline{\underline{z}}, \underline{L})$

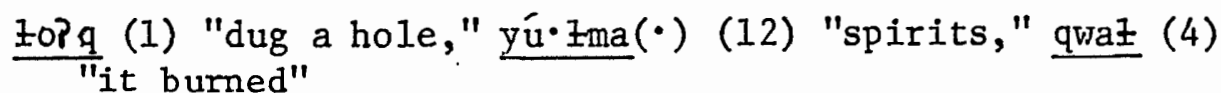

Contrast: /1/ ło? q (1) "dug a hole," lorq (2) "redheaded woodpecker"

pá- Zamtnt (1) "drunk," pá.laqya(?) (3) "medicine man"

$\mid x /$ initial, medial, final.

$[\mathrm{x}](\underline{\mathrm{x}})$

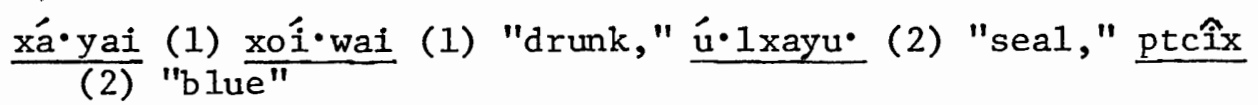

Contrast: /h/ 'u.1xayu. (2) "seal," yólhatca (1) "it is sold" /f / oxotwa.tnt (1) "I cough," fo.fo? (1) "she cooked" See $\mid \mathrm{k} /$

/h/ syllable-initial, syllable-final.

[h] (h) syllable-initial, pre-vocalic.

ha? (11) "up; voice, mouth," púnhä? (2) "he made"

[c] (s) syllable-final, post-vocalic.

mat (17) ma (1) "thou," yas (5) "did"

Contrast: /w/ ha? (11) "up; voice, mouth," wa? (102) "no, not" See $/ \overline{\mathrm{p} /,} / \mathrm{k} /, \mid \mathrm{x} /, / \mathrm{p} /$.

/m/ initial, medial, final.

[m] (ㅍ)

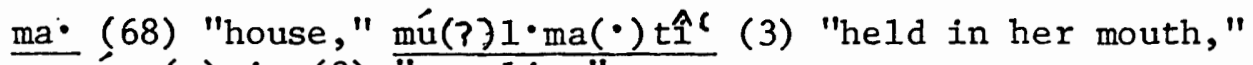
múca(•)yim (2) "sea 1ion"

Contrast: $/ \mathrm{n} /$ na (3) nai (2) "do,"

/n/ initial, medial, final.

[D] inferred to exist before velars.

[n] (n) el sewhere.

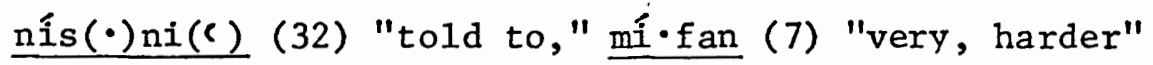


Contrast: / / / na (3) nai (2) "do," $1 a^{\text {l }}$ (2) "excrements"

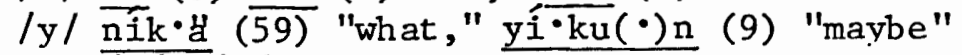
see $/ \mathrm{m} /, / \mathrm{t} /$

/1/ initial, medial, final.

[r] (r) sometimes varies with [1]
büré(?)
(4) bére(?)
(2) béle?
(1) péle?
(1) pơlié?
(2) "big"

$\left[1^{y}\right]\left(1^{\bullet}\right)$ sometimes varies with [1]
$\underline{1 \cdot i \cdot 1 i ? t^{\prime}}$
(1) $1 \hat{i} \cdot 1 E^{?} t^{l}$
(1) "I laugh".

[1] (1) elsewhere.

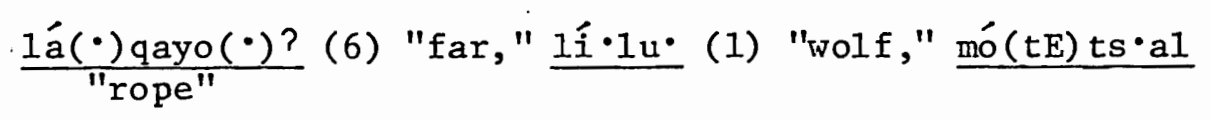

Contrast: see $/ \mathrm{z} /, / \mathrm{n} /$

/w/ syllable-initial.

$[\underline{u}](\underline{w})$

wín'naswi $(\cdot)$ (72) "yes, indeed"

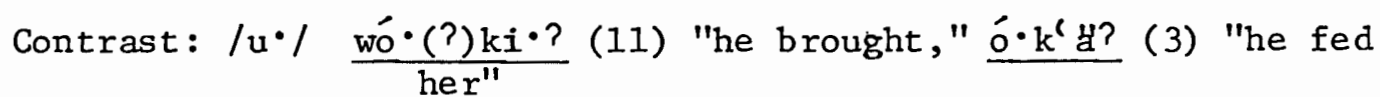
See $/ \mathrm{p} /, / \mathrm{k}^{\mathrm{w}} /, / \mathrm{h} /$

/y/ syllable-initial.

$[\underline{i}]$ (y)

yánat (3) "I'11 visit"

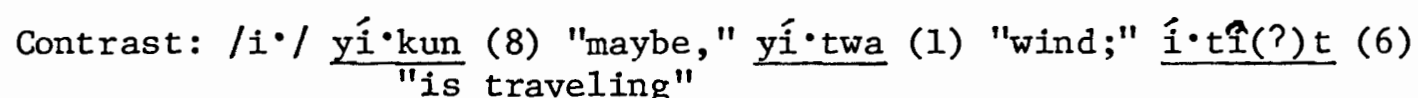
See $/ \mathrm{n} /$

Discussion of Consonants

Palatalization and Length. In consonants, these do not appear to be phonemic. Consonants marked as palatalized vary with those not so marked, and long consonants vary with short ones. In his typescript, as noted, Frachtenberg removes all palatalization marks (no long consonants 
appear in that myth). The length appears to be stylistic. (Consonant length is more common in Tualatin, but there too it is not phonemic.) Velar Stops. Based on this material, $\underline{k}$ and $q$ represent one phoneme. There may in fact be two phonemes involved, but the variation in writing them is such that contrast cannot be asserted with confidence. (In the other Kalapuyan languages, contrast is also uncertain. Frachtenberg notes in his slip files that Yoncalla, Iike Takelma, lacks $q$ and $q$ !; but Jacobs has a $q$ in his Yoncalla materials. There may be a morphophonemic or allophonic relation between [x] and [q] in Yoncalla and in Tualatin, but I have not found such a relationship in Mary's River.)

Frachtenberg had trouble distinguishing [k] and [q]. He says $q$ is often misheard for $\underline{k}$; he often writes one over the other in manuscript; and many forms are written now with $\underline{k}$, now with $\underline{q} \cdot \underline{p k}$ and $\underline{q}$ are also shown as varying sometimes; in fact, all four velar stops may vary. I

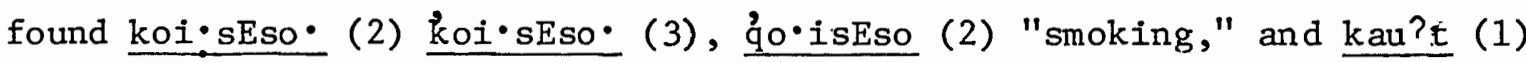
qau?t (14) qqau(?)t (4) "sing;" also kau(•)ta (3) qauta (2) qua·ta (1) "song" (I have normalized most of the vowels in these examples); and there are several others. In his slip files, Frachtenberg lists some pairs of terms which he seemed to intend as examples of contrast, but most of which represent free variation: qta. "ear" and "kta? (or qta?)" "smoke," taqt or takt "to fasten"--there are many other examples. Jacobs also treats [k] and [q] as fluctuating members of one phoneme. He says that Frachtenberg, like himself, uses $\underline{k}$ and $q$ interchangeably in original manuscript (1930:n.p.). He also notes that [k] and [kw] are produced further back in the mouth than they are in English, between the [k] and [q] of Chinook or Sahaptin (Jacobs 1945:14). The acoustic 
results are evident from the tapes of Hudson.

There are some differences in the contexts of $\underline{k}$ and $\underline{q}$, however; they do not always vary freely. Frachtenberg says $q$ is always aspirated, but he writes $\underline{\mathrm{k}}$ that way more often. $q$ occurs only before $\underline{o}, \underline{a}, \underline{a} \cdot, \underline{a u}$, and $\underline{0 \cdot i}$ of the vowels, while $\underline{k}$ appears before front vowels and $\underline{u}$, but rarely before $\underline{o}$. $\underline{I}$ and $q$ tend to appear together, while $\underline{1}$. almost never occurs in the same syllable with q. Possibly more patterning was present, but was obscured by difficulties in hearing and transcribing the differences between [k] and [q]. The trend to environmental conditioning reinforces the conclusion of common phonemic membership.

$/ \mathrm{k}^{\mathrm{W}} /$ appears to be a unit phoneme, not a cluster. Initially and medially, it occurs with the same freedom of occurrence as $/ k /$ before vowels, except that it does not occur before o or $\underline{u}$. Unlike /k/, it does not appear as the first member in initial consonant clusters, but it does occur following initial $/ \mathrm{p} / \mathrm{h} / \mathrm{t} / \mathrm{,} / \mathrm{c} /$, and $/ \mathrm{s} /$. Since clusters seem to be Iimited to two consonants, $/ \mathrm{k}^{\mathrm{W}} /$ is best considered a unit. One advantage to considering it as such is that it can be used to even out the distribution.of [k] and [q] to some extent, since ku can then be interpreted as the phonetic result of $/ \mathrm{k}^{\mathrm{w}} /$ occurring before $/ \mathrm{u} /$, while the conjunction of $/ \mathrm{k} / \mathrm{plus} / \mathrm{u} /$ results in qo.

Glottal Stops and Glottalized Consonants. Glottalization presents a somewhat difficult problem. [P] may not be a segmental phoneme (though I am interpreting it as one), but rather a marker of juncture. In final postvocalic position, however, it contrasts with other consonants, with aspiration (/h/, which may also have marked juncture), and

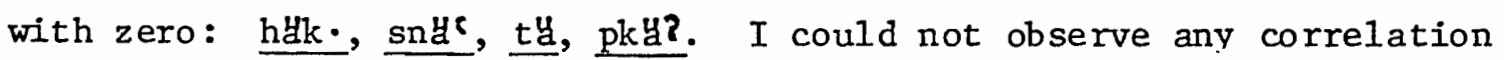


between the occurrence of [?] and any particular initial sound in the following word. Because, as Jacobs says, it was difficult to hear "this impressively elusive phenomenon" (1930:n.p.), it was not always consistently recorded, which makes contrast somewhat difficult to be certain of. It is never written initially before vowels, but almost certainly occurred there; it is audible in that position in John Hudson's taped Santiam speech. Jacobs (1930) says that there are three situations in which the glottal stop is found: (1) as a syllable or word marker (indicated in his texts by dashes, which occur intervocalically or between vowels and resonants); (2) as a stylistic element with no grammatical function, before $C_{1}$ (he seems to mean a syllable-final consonant) in $\mathrm{CVC}_{1}$ or $\mathrm{CVVC}_{1}$ syllables--it appears randomly in such circumstances; and (3) as a "true consonant"--that is, in final postvocalic position. Frachtenberg notes in his slip files that "between two consonants of the same series a $\varepsilon[?]$ is inserted to serve as hiatus," as in tuman $\varepsilon_{n a i}$. That is, geminate clusters are prevented at morpheme boundaries by the insertion of a glottal stop--an example of Jacobs' (1) above. The final postvocalic glottal stop, if it follows monosyllables, tends to be retained in larger constructions, while the glottal stop preceding a final consonant is less often retained. Medial contrasts, such as /wá?la? / "nowhere" and /wálah/ "downhill" are thus created, where the glottal stop serves to mark a morpheme boundary.

In Frachtenberg's material, glottalized obstruents (as in initial p:) are in complementary distribution with sequences of glottal stop plus obstruent (such as final $\underline{\mathrm{p}}$ ). One could consider all these as clusters of $l ? l$ plus consonant, but this would create three-consonant clusters; 
since other consonant clusters seem to be limited to two members, this complicates the clustering patterns and does not seem to solve any problems. Initial glottalized obstruents appear to contrast with plain ones, although the amount of variation between the two in some cases makes it difficult to decide which one a particular form contains. For example, Eau (3) "eel" and taú•?nE (18) "one," and other pairs, show a contrast between $/ E /$ and $/ t /$. But I also found nine instances of tal? and twelve of Zal? "dog," and cannot tell whether the initial phoneme is $/ t /$ or $/ t /$--assuming my analysis is right in the first place. In medial position, where they rarely occur, glottal stops plus consonants probably mark morpheme boundaries, as noted above: In final position, a different pattern obtains. Here, $/ t /$ and $/ c /$ act differently from $/ p /$ and $/ \mathrm{k} /$. $t$ and $\underline{\mathrm{t}}$ appear not to contrast; almost every form containing final $\underline{t}$ has variants with $\underline{t}$, and vice versa. $\underline{\text { ts }}$ is rare in final position (two forms only); ?ts is more common (six forms), but these apparently do not contrast either. While also not contrasting with their unglottalized counterparts, $\underline{? p}$ and $\underline{? k}$, rather than showing free variation, seem to be conditioned in some way, since they occur finally, for the most part, following o or $\underline{a}$ in monosyllables; $\underline{p}$ and $\underline{k}$ occur in these, and other, final environments, so that the conditioning is not very clear. In larger constructions, the glottal stop is retained before $\underline{k}$ in some forms, as it is following vowels in monosyllables, possibly depending on which suffix is added.

?k is particularly obscure, since Frachtenberg sometimes writes it alternately with $q$ or $? \mathrm{q}$, as does Jacobs: "I also write this stop with a glottal catch preceding it: ? k, ?g [Jacobs' underlining]" (1945:13). 
(Since.k does not usually appear before o, some instances of ko may be $\left[\mathrm{qo}^{\circ} \cdot\right)$ The entire region of velar stops--k, $q, \underline{k}, \underline{q}, \underline{k^{w}}, q^{w}, \underline{k^{w}}, \mathfrak{q}^{\mathrm{w}}--$ is a murky one.

$/ \mathrm{k}^{\mathrm{w}} /$ is rather rare and, like $/ \mathrm{k}^{\mathrm{w}} /$, as well as other glottalized stops, it does not occur finally. It varies with $/ \mathrm{k}^{\mathrm{w}} /$ in initial position to an uncomfortable degree: only two forms containing $/ \mathrm{k}^{\mathrm{W}} /$ initially do not vary with $/ \mathrm{k}^{\mathrm{W}} /$, and those consist of only one example each: I postulate the existence of $/ k^{\mathrm{w}} /$, therefore, mainly on grounds of patterning.

Glottalized resonants and fricatives also occur finally; the glottalization is sometimes retained when suffixes are added. Here too glottalization appears to be nonphonemic.

Intermediates, Glottalized Stops, Unglottalized Stops. Jacobs insisted that there were three series of stops in Kalapuyam: aspirated surds, glottalized surds, and "intermediates" (unaspirated surds with occasional brief voicing). He inserted intermediates in Frachtenberg's and Gatschet's texts where voiced consonants were written, and in many other places on principles which are not made explicit. In the hope that Jacobs might shed light on glottalized vs. unglottalized obstruents, and on velars in particular, I examined the distribution of intermediates, glottalized and unglottalized obstruents in Jacobs' treatment of Frachtenberg's material. I found, first, that they do not contrast in / final position. Glottalized stops are rather limited in distribution, generally occurring initially in stressed syllables. In that position, they contrast with unglottalized stops. Intermediates generally do not occur preceding stress; they tend to vary with unglottalized stops 
wherever they occur. This is somewhat confusing, since Jacobs says the intermediates are hard to distinguish from glottalized stops, and that they are often recorded inconsistently:

The texts are full of inconsistent recordings of $D$ [the capitals represent intermediates] for a phonemic $\underline{k}, \underline{G}$ for $\bar{a}$ phonemic $\underline{k}$, because ... the acoustic effect of the articulation of a glottalized consonant is so little different from the articulation of an intermediate stop (Jacobs $1945: 151$ ).

His treatment of the Mary's River material, however, shows greater patterning than is visible in his own Santiam, for some reason. Whatever the status of intermediates, Jacobs' treatment of Mary's River tends to confirm what I found, that glottalized and unglottalized stops contrast in initial position.

There seems to be evidence for two phonemic obstruent series. Shipley (1970:98) maintains that the contrast in proto-Kalapuyan is between aspirated and unaspirated. However, Frachtenberg sometimes writes aspiration after both glottalized and unglottalized stops, so aspiration obviously cannot be used to sort out the two series, in Mary's River, at least. They may be glottalized-unglottalized, fortis-lenis, or clusters vs. single stops, but not aspirated-unaspirated.

Aspiration. In general, aspiration presents a problem, mainly because Frachtenberg seems to be so inconsistent in recording it. He says that glottalized consonants, $q$, and final voiceless consonants preceded by $\underline{n}$, are automatically aspirated, but he seldom writes them that way in the manuscripts. And Jacobs notes that the surds are aspirated as much as, or more than, in English (1930:n.p.). In the manuscripts, aspiration is shown finally after $\underline{k}, \underline{q}, \underline{t}, \underline{?_{k}}, \underline{{ }_{\mathrm{q}}}, ? \underline{t}, \underline{? \mathrm{~m}}$, and $\underline{?_{I}}$; the same forms are also written without aspiration. $\underline{k}$, and sometimes $\underline{t}$; are occasion- 
ally shown aspirated in initial or medial position. Some of these instances, especially with $t$, are apparently transitions between conson-

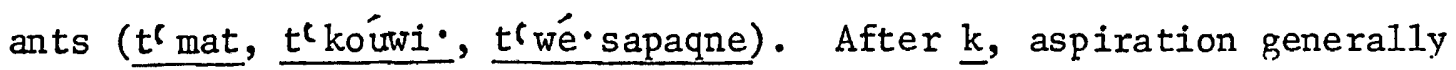

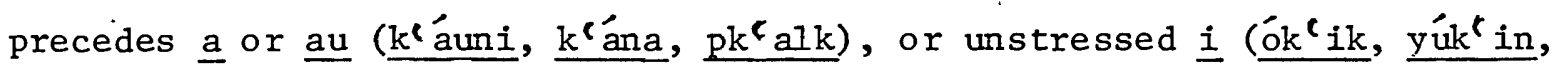

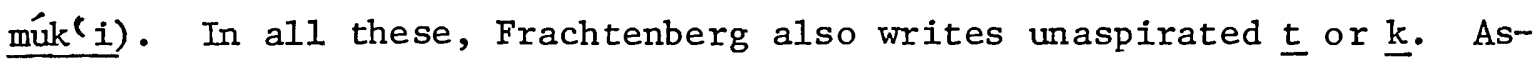
piration also sometimes marks juncture medially; in these cases, as with $[?]$, it appears to be retained when a form with final postvocalic aspiration, or final $t^{l}$, is compounded (tcótnak, tamít $\underline{t^{l} w o ? k}$ ). [h] and [t] are in complementary distribution, since the latter is syllable-final and the former syllable-initial. Like [c], [h] can be used as a morpheme boundary marker medially, since it only occurs syllable-initially and does not cluster with other consonants (púnhü?).

Frachtenberg's typescript of the fifth myth is interesting with regard to aspiration. In it, morphemes are separated even more often than they are in the manuscript version. Aspiration is added rather regularIy to forms shown without it (and retained, usually, for those with it) in the manuscript: it is present after all final $\underline{t}$ and $\underline{? t}$, after $\underline{k}$ and $\underline{?_{k}}$ if they follow back vowels, and apparently after $\underline{p}$ and $\underline{p}$ in the same environment (some vowels had not yet been inserted in the typescript, to judge by the manuscript; spaces were left for them). The similarity to the distribution of final [?] plus stop is clear: grave stops appear to act alike. (It is noteworthy however that in the manuscripts $p$ is not written aspirated.) That is, $\underline{\mathrm{p}}$ and $\underline{\mathrm{k}}$ may be written with a glottal stop if they follow back vowels in monosyllables, and they may be aspirated in that environment, glottalized or not. $t$, on the other hand, freely varies with $\underline{\text { t }}$, and both are always shown aspirated in the typescript. 
It is possible that some consonants which Frachtenberg sometimes writes aspirated were in fact glottalized. (Hymes [1966:333] says the same for Frachtenberg's transcription of Siuslaw.) Glottal stops written alone are not shown aspirated, but sometimes a rearticulation of the vowel appears: $\underline{f_{a}}$ a . There are a few instances of variation between [?] and [C] in final postvocalic position as well.

I have kept aspiration in final postvocalic position as an allophone of $/ \mathrm{h} /$, since it seems to contrast with other consonants, $/$ ? , and zero, as already noted. It occurs almost entirely after short vowels in that position; $/ ? /$ and nothing also occur following long vowels and diphthongs (final vowels can be long, short, or diphthongs).

Fricatives and Affricates. / $x /$ is rare; I have found it in only six forms. Since it was rare, Frachtenberg paid attention to it when it occurred, and did not vary in recording it. Two of the forms are borrowings from Chinookan (úlxayu., "seal," probably of Lower Chinook origin, and ptcix, "blue," from Chinook Jargon), indicating a possible source of the sound. It is written more often in texts of other Kalapuyan languages, however, possibly varying allophonically or morphophonemically with q.

/f/ is phonemic, contrasting with $/ \mathrm{w} / \mathrm{h} / \mathrm{h} /$, and $/ \mathrm{p} /$, but its morphophonemic relationship with $/ \mathrm{w} /$ and maybe $/ \mathrm{h} /$ is problematic. It was a bilabial voiceless fricative at least in the central dialects and Yoncalla, but Yamhill and possibly one informant in Tualatin appear to have had a labiodental [f]. Frachtenberg says for Mary's River that $\underline{w}$ "looses its sonancy" after $\underline{t}$ and becomes $\underline{f}$, but he always writes $\underline{t w}$. (He reverses this for Tualatin, saying that $\underline{f}$ becomes $\underline{w}$ after $\underline{t}$, $\underline{t}$, and 
$\underline{q}$, but as examples he gives tsfan, not tswan, in addition to tswi. and tswo..) In Santiam, Jacobs says that he often records $\underline{f}$ as $\underline{f w}$ and $\underline{h}$ : that it is a "peculiar hw or Xw sound," as in "which" or nonsense "fwich" (1930:n.p.), and that the relations between $\underline{h}, \underline{h^{W}}$, $\underline{f}$ and $\underline{f^{\mathrm{W}}}$ are not clear in Santiam (1945:14). Apparently referring to all the Kalapuvan languages, Swadesh says that he writes wh or hw for /f/, "because it is evidently the cluster of w with aspiration" (1965:237). Frachtenberg does not record $\underline{h^{\mathrm{W}}}$ or $\underline{\mathrm{x}}^{\mathrm{W}}$ for Mary's River, but there are some central Kalapuya-Yoncalla correspondences in his slip files in which $\underline{f}=\underline{x_{w}}$, and there is also a hu- $=$ wu-. $/ \mathrm{f} /$ is thus probably derived historically from a rounded velar fricative. It is extremely rare in the Northwest, being found only in Kalapuyan and in the Neighboring Molala.

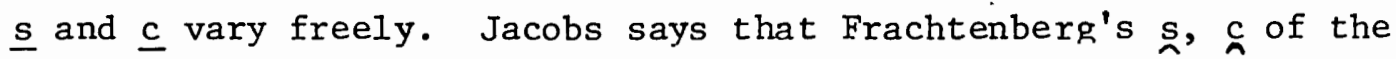
slip files--equivalent to s., $\underline{c}$ - in the manuscripts--represent a sound "intermediate" between [s] and [š (1930:n.p.)--possiblv an alveopalatal slit fricative.

$\underline{\text { ts }}$ and tc also vary freely. They occur in all positions, contrast with $\underline{t}$ and $\underline{s}$, and also enter into initial clusters; thev evidentlv represent a unit phoneme, $/ \mathrm{c} /$. (See discussion of clustering belor.)

Resonants and Glides. /I/ may have had fronted and backed allophones. As noted earlier, the palatalized 1 - almost never occurs with the back velar $\underline{q}$, but it may often. be found with $\underline{\mathrm{k}}$. Both $\underline{\mathrm{k}}$ and $\underline{\mathrm{q}}$ are found with unpalatalized. 1 . The apparently inconsistent recording makes it difficult to state the conditioning, however. There was an I allophone, occasionally varying with $\underline{I}$ intervocalically.

$\mid y /$ and $/ w /$ are phonemically distinct from $/ i /$ and $/ u /--y \hat{i}--$ and 
í- contrast, for instance--but the consonants may be related morphophonemically to the vowels. Their distribution could be extended to final position by writing the final elements in diphthongs as $/ \mathrm{y} /$ and $/ \mathrm{w} /$ (see discussion of vowels and diphthongs).

/m/ and /n/ are quite straightforward. /n/ before $\underline{k}$ was probably [ᄁ], as in Hudson's Santiam speech, but Frachtenberg onlv records $\underline{n}$. Consonant Clusters

In initial and final position, consonant clusters appear to be limited to two phonemes. Word-medially, three-phoneme sequences occur sometimes (e.g., /púncpupat/, "were swimming"), but I have found onlv one sequence of four (/swánkswaku./, "crawled"). These three- and fourphoneme sequences apparently involve a morpheme boundarv, although I am not always able to identify it (/swank/ + /swaku·/; /punc-/ "became" + /pupat/). In finding morpheme boundaries, the presence of non-clustering consonants or impossible sequences is helpful, but these are not always present (see below). Frachtenberg mentions "permissible sound groupings," without listing them, and says that all suffixes are added to stems by means of a connective vowel, so clearly the clusters which could occur were limited. However, he gives "exceptions" with no intervening vowel, and in the manuscripts he does not alwavs indicate such a vowel either. In discussing syllable structure, Jacobs (1930:n.p.) savs that phonetically no consonant clusters exist, since an epenthetic vowel is always inserted after the first consonant (CCV $=\mathrm{C}[\mathrm{V}] \mathrm{CV})$, and $/ \mathrm{y} /$ after a stop does not count as a consonant. He too does not show "intervening vowels" consistently. An examination of medial clusters has therefore not proved very enlightening; I do not list them here. 
These consonant phonemes do not cluster finally and initially: $/ 1 /$; $/ \mathrm{x} /, / \mathrm{h} /, / \mathrm{l} /$ (according to my analysis, final clusters of [?p], etc., are non-phonemic; these are discussed later). Thus, when these consonants turn up in medial clusters (such as in púnhä) I can be confident a morpheme boundary is involved.

Initial clusters found are as follows:

Second Member

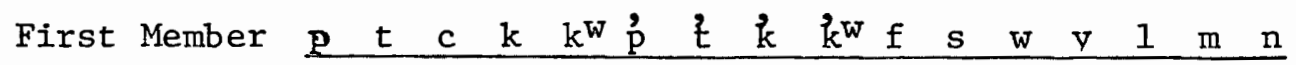

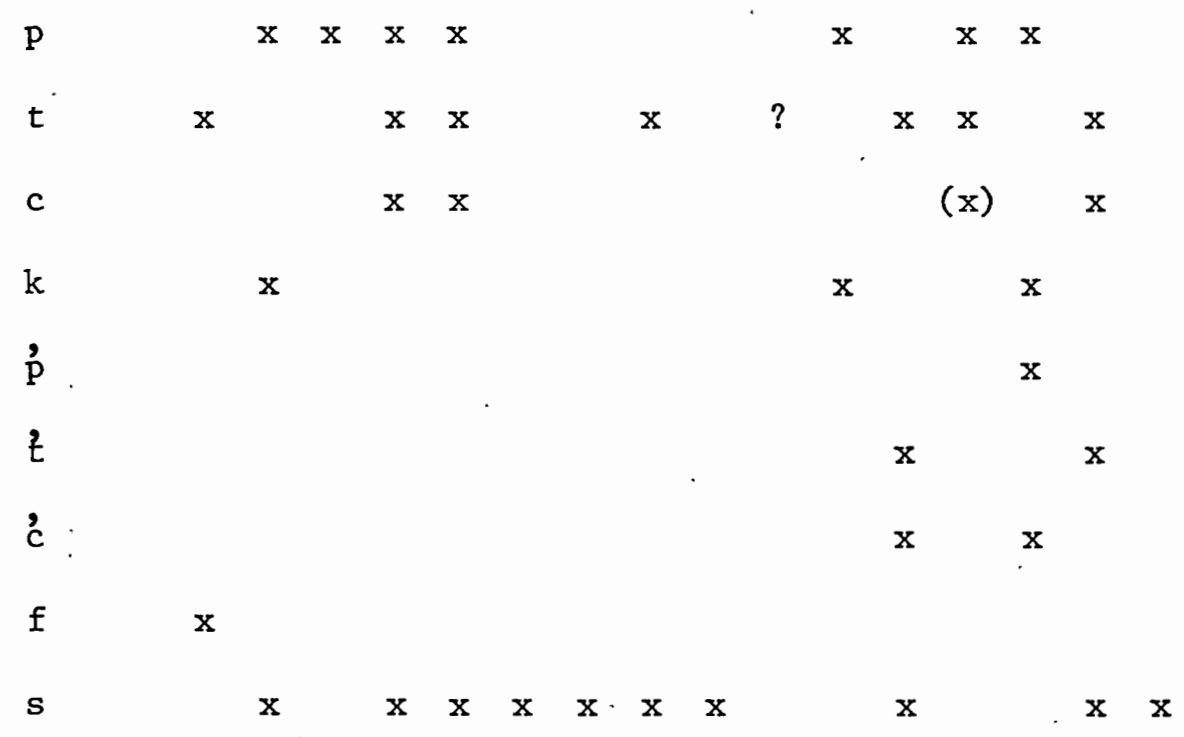

In initial clusters, $/ \mathrm{p} /, / \mathrm{t} /, / \mathrm{c} /, / \mathrm{k} /, / \mathrm{p} /, / \mathrm{t} /$, and $/ \mathrm{s} /$ occur in either first or second position. / $\mathrm{f} /$ may also, if Frachtenberg's tw is really $/ \mathrm{tf} / . \mid \vec{c} /$ only occurs first in this material. $/ \vec{k} /, / \hat{k}^{\mathrm{w}} /, / \mathrm{k}^{\mathrm{W}} /$, $/ \mathrm{w} /, / \mathrm{y} /, / 1 /, / \mathrm{m} /$, and $/ \mathrm{n} /$ occur only as second members. That is, sequences of obstruent plus obstruent, fricative, or resonant, or sequences of fricative plus obstruent or resonant may occur. There are no geminate clusters within Frachtenberg's word boundaries, except as stylistic variants. There is only one instance of /fp/ (/fpi/, "gopher"), 
but it seems reliable. /cy/ occurs only as a variant of tcEy-; the schwa is either one of Frachtenberg's intervening vowels, or an allophone of $/ \mathrm{i} / \mathrm{g} / \mathrm{m} /$ and $/ \mathrm{n} /$ can function as syllabics; some apparent initial clusters with $\underline{m}$ and $\underline{n}$ in initial position are examples of this. In medial position, clusters such as the nf in psinfo? indicate a morpheme boundary.

Final clusters, excluding sequences of glottal stop plus consonant, are much simpler:

Second Member

\begin{tabular}{|c|c|}
\hline Pirst Member & $\begin{array}{llll}p & t & c & k \\
\end{array}$ \\
\hline $\mathrm{m}$ & $\mathrm{x}$ \\
\hline $\mathrm{n}$ & $x \quad x(x)$ \\
\hline 1 & $x(x)$ \\
\hline
\end{tabular}

I infer the existence of $/ 1 \mathrm{t} /$ and /nk/ from the occurrence of $\underline{\text { It }}$ and ?nk. Final clusters are limited to resonants plus obstruents.

In final position, glottal stops occur with consonants as follows:

$\begin{array}{llll}\text { ?p } & \text { ?f } & \text { ?m, m? } & \mathrm{m} ? \mathrm{p} \\ \text { ?t } & \text { ?s } & \text { ?n, n? } & \mathrm{n} ? \mathrm{t}, \text { ?nk } \\ \text { ?c } & \text { ?t } & \text { ?1,.1? } & \text { ?1t, ? } 1 \mathrm{p} \\ \text { ?k } & & & \end{array}$

As noted earlier, glottalization appears not to be distinctive in this environment. When the glottal stop occurs with final consonants, Frachtenberg most often writes it preceding obstruents and fricatives, but either preceding or following resonants. Thus, it seems probable that the articulation of the glottalization occurred simultaneously with the 
resonants. It would probably be useful to retain writing the glottal stop finally with consonants in those cases where it is retained morphophonemically in larger constructions, even though it appears to be nonphonemic.

Vowels and Diphthongs

/i/ initial (rare), medial, final; stressed and unstressed.

[8] (b) varies with [e] in one form: [y] unstressed, following /p/, [e] stressed.
$\frac{\text { byré(?) (4) bére(?) }}{(2) \text { "big" }}$
(2) béle?
(1) péle?
(I) püre?
(1) pblé(?)

[E] (브) initial; medial, stressed; final, unstressed.

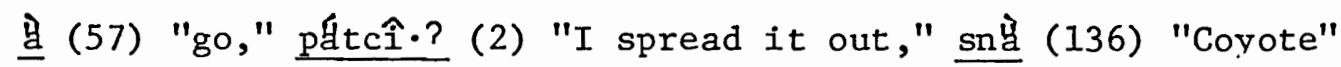

[e] (e) initial (rare), medial, final; stressed and unstressed. énai (3) "they go," me?m (62) "people," tcî̉nte (54) tcî́ntu (5) "we will (?)"

[i] (i), [2] (ㅅ) may not occur initially; medial, final; stressed and unstressed.

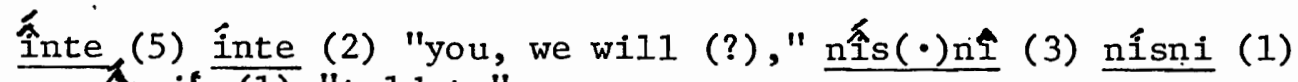
nisnit (1) "told to"

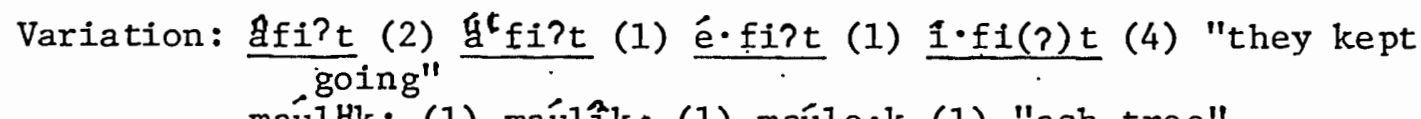
maúlhk• (1) maúlị̂k·(1) maúle·k (1) "ash tree"

kumantry (25) kumánta (5) kumante (6) kumántî (12) kumanti (22) kumanta (2) kumánti. (3) "again (?)"

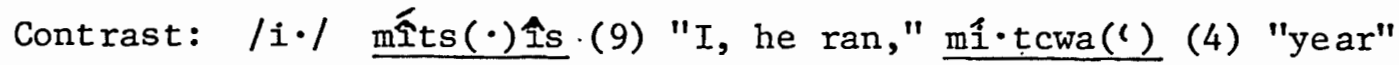
/i $/$ initial, medial, final; stressed and unstressed.

[e·] (e्) initial, medial (especially if stressed), final (only as variant). é-fa?m (5) "her, his father," mé·fo? (3) "hill, mountain"

[i·] (프) initial, medial, final; stressed and unstressed. $\underline{i \cdot c t(E) f a(?) t(c)}$ (2) "small," tcíi.pkam (8) "long ago," 
ó·tni·hł? (5) "call him," yi• (54) "go home"

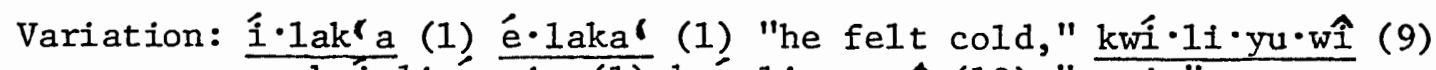

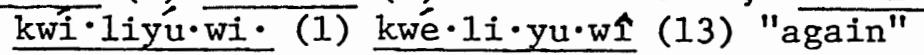

/a/ initial (rare), medial, final; stressed and unstressed.

[a] (a)

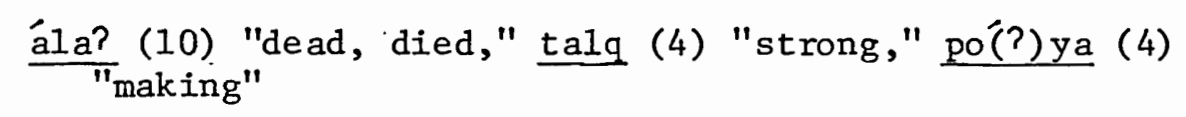

Contrast: /a./ ála? (10) "dead, died," á.na? (12) "his daughter" /a $/$ initial (rare), medial (especially if stressed), final (rare); stressed and unstressed.

$[a \cdot](\underline{a})$

$$
\begin{aligned}
& \text { a.na? (12) "his daughter," tátsi?t(c) (8) "lived there," }
\end{aligned}
$$

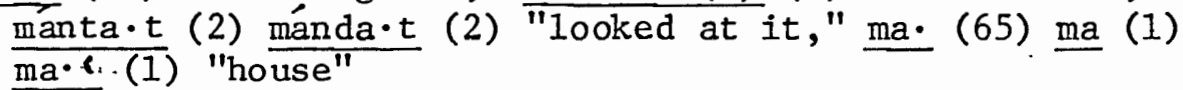

/u/ initial, medial, final; stressed and unstressed.

[u] (u) medial; final only as variant; stressed and unstressed (somewhat more common unstressed).

$$
\text { muf (10) "grouse," túkulhu? (1) dúkulhu? (1) "ow1" }
$$

[o] (o) initial, medial, final; stressed and unstressed (somewhat more common stressed).

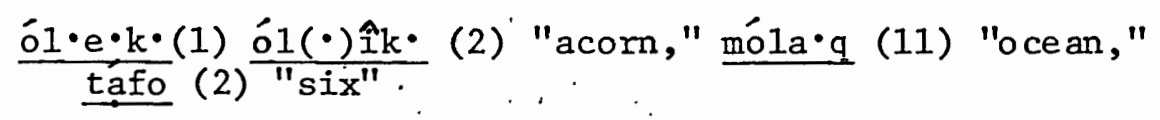

Variation: múlma $(\cdot) t \hat{i}\left(\right.$ (?) (2) mó? $1 \mathrm{ma} \cdot t \hat{1}^{\text {s }}$ (1) "held in her mouth," i०cto? (1) i:ctu :? (1) i०s:tu? (1), "small"

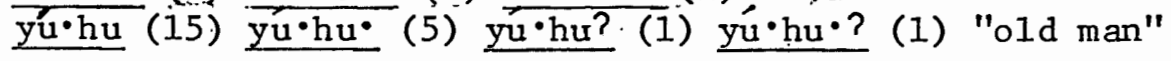

Contrast: $/ \mathrm{u} \cdot / \frac{\mathrm{t}\left({ }^{\prime}\right) \text { óki }(\cdot) \text { ? }}{\mathrm{tu} \cdot \mathrm{pi}(\cdot) \text { ? }}$ (5) "he, I finished," tó (moon"

/ u / initial, medial, final; stressed and unstressed.

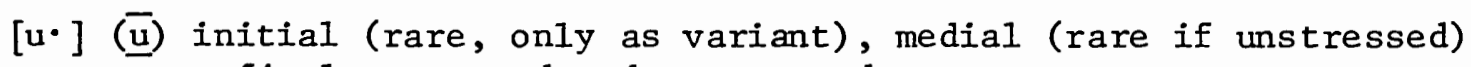
final; stressed and unstressed. yú•wa(?)I (12) "hunting," yé•1a?yu• (2) "get well"

[o·] (ㅁ) initial; medial, stressed; final only as variant. 
o-krup? (3) "he fed her," wo•?k (59) "there, arrived"

Variation: 'u-fo? (1) o

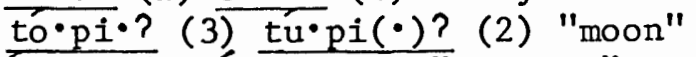

okwu' (2) okwo (2) "feed us"

/ai/ medial, final; stressed and unstressed.

[aij] (ai) final, unstressed.

gó-tkai (24) "got up, woke up"

$[a \cdot \underline{i}]$ (ai $)$ medial, final (rare); stressed.

waíttap (6) "camped"

Contrast: /i./ maí.tco? (24) "tomorrow," míltcwa(') (4) "year" la./ qwaín- (4) "swim," kwai·k (2) "leaves, bushes," qwa.z (2) "cottonwood"

/au/ medial, final; stressed, unstressed.

[au $]$ (au)

$\frac{\text { tkáuwi. (4) "he, I threw it," a.lau?kam (2) "when did," nau }}{(24)}$ "and"

Contrast: /a./ wa.úso?, waú.so? (10) "nobody," wáts·a?tc (1)
$/ a \cdot u / \frac{\text { káutcEma }}{\text { money" (3) "door," káu.watca(?)t(?) }}$
(2) "Indian
$/ \mathrm{u} \cdot /$ mau (6) "white," mu.
(1) $\mathrm{mo} \cdot \mathrm{r}$
(1) "black"

/a.u/ medial, final (in one form); stressed.

$[\mathrm{a} \cdot \underline{\mathrm{u}}](\underline{\mathrm{au}})$

káu.watca(?)t(c) (2) "Indian money," wau• (1) "nobody"

/ui/ initial, medial, final; stressed.

$\left[y \cdot i{ }_{\lambda}\right](\underline{\bar{y}} i)$ varies with $[0 \cdot i]$ in one form

$\frac{1(\cdot) 8 i \cdot ?}{\text { "much, }}, \frac{1(\cdot) 8 \cdot i ? ?}{\text { many" (6) } 18 i ? \text { (2) } 1 \cdot 0 \cdot i \cdot ?}, \underline{1 \cdot 0 \cdot i ?}, \underline{1 \cdot 0 i \cdot ?}$

$\left[0^{\circ}\right.$ i $]$ ] (ㅁi) elsewhere

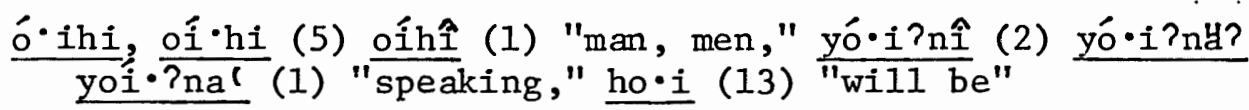




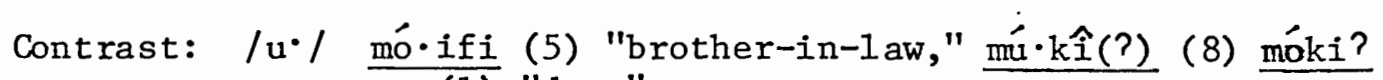 (1) "deer"

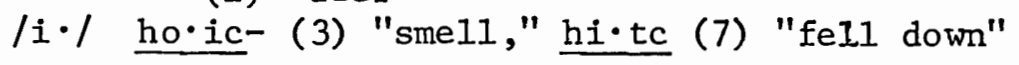

Discussion of Vowels and Diphthongs

Vowels. As can be seen, the distributions of vowel allophones are not neat. There is a great deal of variation or inconsistency in vowel length and quality in the manuscripts, and I may have failed to observe what patterns do exist in some cases. The existence of rhetorical length is a probable cause of some of the variations in length. Still, length does appear to be phonemic for the simple vowels, and apparently for $/ a \cdot u /$. On the analogy of the short diphthongs, long vowels would best be treated as sequences of two short ones: /ii/, etc. Because /au/ and $/ \mathrm{a} \cdot \mathrm{u} / \mathrm{seem}$ to contrast, however, I prefer to avoid three-vowel sequences by writing $/ i \cdot /$, etc., not /ii/.

No vowels, are common initially (if the a-, an- noun marker prefixes and the $\underline{\mathbf{u}} \cdot$, um prefixes (adjectival? verbal?) are disregarded, as Frach-

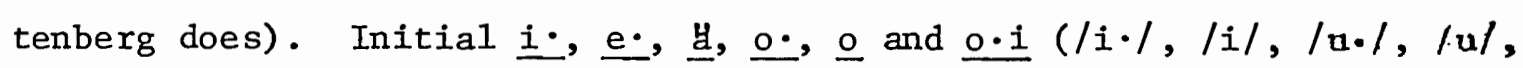
/ui/) are found in at least three forms each. Vowels tend to be more

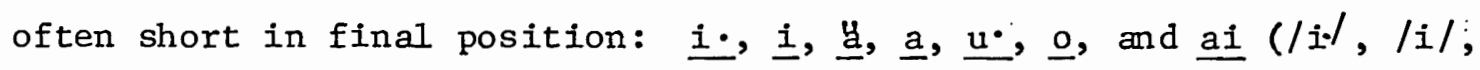
$\mid \mathrm{a} /, / \mathrm{u} \cdot /, / \mathrm{u} /, / \mathrm{ai} / \mathrm{l}$ are most common. They tend even more often to be short in medial unstressed position: Although stress and length are independent, there is some tendency for long vowels to appear stressed more often than they appear unstressed.

[i] and [e] vary with each other, but perhaps less often than mem-

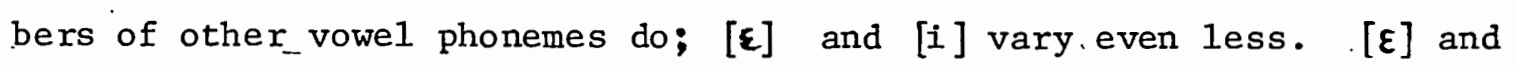
$[e]$, and $[\varepsilon]$ and $\left[e^{\cdot}\right]$, vary quite commonly, however. (Tualatin may have two phonemes in this area, /i/ and /e/ (Jacobs:n.d.), but Mary's River 
does not.) Unstressed $\hat{\underline{i}}$ represents a non-phonemic epenthetic vowel a number of times (probably [ij] rather than an allophone of $/ i /$ ), and $I$ may have missed some of these.

/a/ occurs most often of any vowel. Shipley is probably right in saying that it represents the falling together of some earlier vowels (1970:98). It varies rather little with other vowels, as transcribed bv Frachtenberg; most variations are with $\mathrm{a} \cdot$, less often with $\mathrm{E} . / \mathrm{a} \cdot /$ is quite limited in distribution, being found mostly stressed mediallv.

There is no problem about the common phonemic membership of [u] and $[0]$, or $[\mathrm{u} \cdot]$ and $[\mathrm{o} \cdot]$. They vary freely with each other, though the long vowels vary more freely than the short.

Diphthongs. These are close-knit sequences, having the same freedom of occurrence as single vowels generally. They could be written with $|w|$ and $|y|$ as second elements, but this would obscure the fact that the vowel clusters with $\left[\mathrm{u}_{n}\right]$ and $[\underset{\mathrm{i}}{\mathrm{i}}]$ in second position are distributed much like single vowels, while those with [uㅅ] and [ị ] preceding other vowels are like other consonant plus vowel sequences. For instance, those diphthongs which are followed by $/ ? /$ (the second element is never preceded by $/ ? /$ ) in final position seem to behave like single vowels followed by glottal stop in that the stop is often retained when suffixes are added.

The diphthongs have even less neat distributions than single vowels, however. Except for $[0 \cdot 1]$, they are not found initially, and $[a \cdot u]$ is only found finally in one form. They almost never vary with single vowels, though Frachtenberg hints now and then that thev should. Jacobs says that "long diphthongs are perhaps rarely if ever found in 
Kalapuya. The reason he [Frachtenberg] may have found for such indication of lengthening of vowels I have not been able to learn" (1945:147). However, length is clearly conditioned by stress in the case of [a.i] , and $[0 \cdot i]$ is consistently long. It would be convenient to get get rid of the $/ \mathrm{a} \cdot \mathrm{u} / \mathrm{I} / \mathrm{au} / \mathrm{contrast}$, but, though modal $[\mathrm{a} \cdot \mathrm{u}]$ tends to vary with [aun], they do not show any more conditioning than do short and long single vowels.

The peculiarities of $[0 \cdot i]$ ] suggest to me that it may consist of two syllables rather than being a diphthong. One reason for thinking so is that it is the only diphthong found in initial position. Another is the way Frachtenberg marks length of diphthongs in the manuscripts--he most of ten writes $\underline{\text { au }}$ and $\underline{a \bar{i}}$, with the second element long, but $\overline{\bar{o}}$, with the first long. It is true that in the typescript he moves the length mark to the first element of $\underline{\overline{a u}}$ and $\bar{a} \underline{i}$, but the original difference in transcription is interesting. However, if $[0 \cdot i]$ really is two svllables, not one, there is a problem in how to interpret it. Frachtenberg never varies such forms as höi "be" with anything like thowi or thuwi: other forms do contain such sequences, as in yú.wi "again." Because of this probable contrast, I am leaving $\left[0^{\circ} i\right]$ as /ui/, although I suspect this is not the right solution.

The Problem of Schwa. [0] is apparently not phonemic. It appears in three types of contexts: (1) as a substitute for other vowels. It is modal only twice, and in both cases is probably a variant of [e]/in final

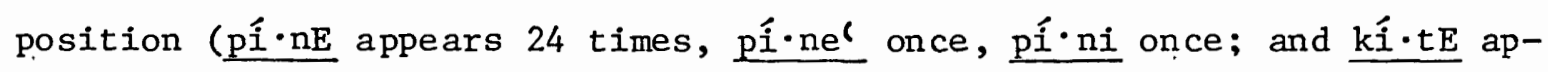
pears six times, kíte once). It occurs short and unstressed with very few exceptions, and varies more with other vowels than anything else 
does. Since it occurs as a substitute for other short unstressed vowels (especially $\underline{i}$ medially and $\underline{e} / \underline{\underline{O}}$ finally) it is often rather difficult to sort out. Jacobs maintains [o] is a variant of /a/ (and also of / $i /$ and $/ u /$ ), but in this material it most often replaces/i/. An indication of which vowel is being replaced is sometimes given by the preceding vowel, or by the surrounding consonants, as in the examples above. $\hat{\underline{1}}$ often appears varying with $\underline{E}$, or in situations where $\underline{E}$ might be expected; it probably represents $[\dot{i}]$ in these cases, as it seems to do in Siuslaw (Hymes $1966: 342$ ).

(2) [ə] (and [i]) occurs as an epenthetic vowel, serving as a transition in consonant clusters and possibly marking morpheme boundaries. As mentioned earlier, Frachtenberg notes in his slip files that "all suffixes are added to stems by means of a connective vowel (a, $u$ ) regardless of whether cluster is permissible or not" (and then Iists exceptions with no intervening vowe1); he also gives $\underline{i}$ and $\underline{E}$ as such vowels. The variation may reflect consonant qualities: $\underline{E} \sim \underline{\hat{i}}$ mostly after or between $/ t /$ and $/ c /$.

(3) A third use for [ə] is with a syllabic nasal. In Frachtenberg's typescript, he has inserted $\underline{E}$ before nasals which were written without a preceding vowe1 in the manuscript. Although both Jacobs and Frachtenberg seemed to feel that a [ə] was "realiy" present before syllabic nasals, it is more economical not to postulate phonemic /a/ just for this position.

In saying that [ə] replaces several vowels, I have violated a cardinal rule of the American descriptivist tradition: each segment of sound must be assigned to some phoneme, and each segment must be assigned 
to only one phoneme (the "biuniqueness criterion"), so that a phonemic transcription can be unambiguously and directly readable, and any utterance has only one phonemic transcription. For instance, Gleason (1961: 294-295) gives the example from some English dialects of the neutralization of alveolar stops in intervocalic position (e.g., "latter" and "ladder" sound alike). The solution, he says, is either to equate the neutralized stop $(/ \mathrm{T} /)$ with one or the other alveolar stop $(/ \mathrm{t} /$ or $/ \mathrm{d} /)$, or to maintain it as some sort of separate element. But if one takes the latter course, "what is the status of /T/ in the system?" American 1inguists prefer to match the anomalous stops, some Europeans would main$\operatorname{tain} / \mathrm{T} /$.

Thus, if I were to be methodologically correct, I would have to assign [ə]to some vowel phoneme, probably /i/ since [ə] joccurs most often

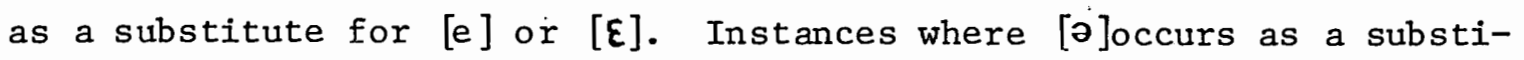
tute for $/ a /$ or $/ u /$ would then have to be interpreted as phonemic variation. This is not a very satisfactory solution, since what happens is clearly not the substitution of one phoneme for another, but the loss of contrast between phonemes. (As some perhaps apocryphal linguist is supposed to have said, "Biuniqueness is a damn nuisance.") Other methods of linguistic analysis might well deal better with this problem, but since I am committed here to using a descriptive approach, the awkwardness remains. I have not listed [ə] in the phonemic inventory as an allophone of anything; depending on the reader's theoretical preference, it may be considered to belong to /i/, to a1l vowels, or to be a separate element. 


\section{Suprasegmentals}

Frachtenberg occasionally does not mark stress, but he is remarkably consistent when he does show it. It occurs on both short and long vowels, and is thus independent of length, even though in at least. one case (/ai/) it conditions length, and even though long vowels are more often stressed than unstressed. In Mary's River, it falls on the first syllable of a stem; in Tualatin and Yoncalla, stress is often shifted to prefixed elements. If a prefix is added in Mary's River, stress does not move: waú.tso?, kuwaú.tso?. Stress is accompanied generally by higher pitch (sometimes perhaps by lower pitch), which Jacobs calls "pitch accent." He says that pitch accent falls on "every syllable felt to be an independent root--nominal, pronominal, connective, or verba1" (1930: n.p.). Since stress is not always predictable from the segmental construction alone, it is considered to be phonemic.

Frachtenberg records two sorts of pitch: ' (falling) and ' (rising). The $\sim$ often varies or coincides with a length mark, and occurs on medial (sometimes initial) vowels, usually o or … The 'occurs most often at the ends of syntactical units, but not always. In some cases it seems to co-occur with stress to form the pitch accent; this may account for the fact that a few words are typically marked with falling

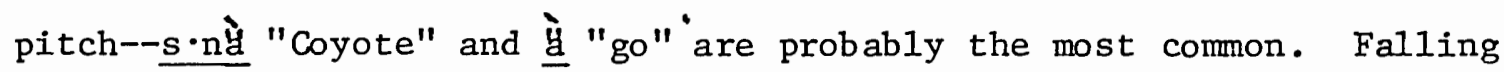
pitch is a good deal more frequently marked than is rising pitch. It is probably part of an intonation contour, and the $\sim$ is probably stylistic.

\section{Sy1lable Structure}

Canonical form is evidently (C) $V(C)$, where $C$ represents one or two consonants and $\mathrm{V}$ can be a short or long single vowel, diphthong, or 
nasal. Since diphthongs, except for /ui/, do not occur initially, no W or VWC sequences occur as monosyllables; neither, apparently, does NC. Otherwise, all possibilities are realized.

In final position, some vowel distinctions appear to be lost (short vowels may become $[\vartheta]$, for instance), as do the distinctions between glottalized and unglottalized consonants and $/ \mathrm{k} /$ and $/ \mathrm{k}^{\mathrm{W}} /$.

Initial vowels are not common; it is possible that these are all preceded by glottal stops. In word-final position, particularly after short vowels, /?/ and /h/ may act to fill a final consonant slot; but short vowels also occur finally with nothing written following them, and long vowels and diphthongs occur followed by /?/ and $/ \mathrm{h} /$. Thus, the evidence is not clear enough to pernit the conclusion that the canonical form is CVC rather than (C) $\nabla(C)$. 
CHAPTER III

SUMMARY AND CONCLUSIONS

\section{Summary}

After considerable exposure to Frachtenberg's transcriptions, my respect for his probable phonetic accuracy is rather high. When his recordings appear to be inconsistent, it is likely that his informant often was inconsistent in his speech. He, like Jacobs later (and Gatschet earlier) had trouble with the velar stops and with vowels to some extent, but Jacobs' judgment that Frachtenberg's phonetic work is "seriously defective" (1945:204) seems considerably overstated. Frachtenberg evidently shared the common goal of linguists of his day, to record phonetic detail as accurately as possible; the concept of the phoneme, after all, was hardly in widespread use in 1914. Later, Jacobs was influenced by phonemic theory; while his texts are not phonemicized, they show evidence of considerable (perhaps intuitive?) regularization.

The problems I have faced in phonemicizing Frachtenberg's transcriptions therefore are not, as $f a r$ as I can tell, due to his lack of phonetic skill; rather, perhaps the reverse, since the material was not elicited with a view to eventual phonemic analysis. Frachtenberg was not concerned with whether ma and mal ("thou") were "the same" or not, but with whether those were accurate recordings of what Hartless said.

It is possible that an examination of more than the six myths with which I worked would reveal more of the structure and help resolve the remaining uncertainties. More likely, the ethnographic texts should be 
examined, to compensate for whatever stylistic peculiarities the myths possess--in particular, some of the rhetorical lengthening might be sorted out in this way.

To recapitulate briefly: I tallied each occurrence of each form (Frachtenberg's "words," those items written with spaces on each side) in the first six Mary's River myths collected from William Hartless. Those forms which occurred most frequently--the "modal" forms--were first compared to reveal distributional patterns; tentative phonemic contrasts, or allophonic variations, were set up. Then the single instances and non-modal variants were examined, to help confirm or modify the emerging phonemic patterns.

I arrived at a system of 21 consonants, six vowels, four diphthongs, and phonemic stress. This includes two obstruent series, glottalized and unglottalized, five fricatives, three resonants (two nasals and one voiced lateral), and two glides. The vowels occur in three positions-high to mid front, low center, high to mid back--with two degrees of length. Length is distinctive for one of the four diphthongs as well, since I was unable to account for the distribution of $/ a$ u $/$ and $/ a \cdot u /$ other than by postulating contrast.

Four consonants had palatalized allophones: $/ \mathrm{c} /, \mathrm{s} / \mathrm{s} / \mathrm{k} /, / 1 /$. Two stops had voiced allophones: / $/ \mathrm{h} / \mathrm{p} /$ (and possibly $/ \mathrm{k} /$ as well; Frachtenberg's writing makes $g$, if it occurs, indistinguishable from q.) The velars were so distribuţed that it was necessary to put $[\mathrm{q}]$ and $[\mathrm{k}]$ together, although it is possible that they are really in contrast. I have no confidence that their distribution has been sorted out adequateIy from each other or from that of [q] and $\left[k^{2}\right]: / k^{w} /$ and $/ k^{w} /$ also 
have rather random distributions and may not contrast. All glottalized consonants have 1imited distributions, being found only initially. As they are treated here, /w/ and /y/ also have only-initial distributions. Finally, sequences of glottal stop plus consonant (obstruent, fricative, or resonant) vary with plain consonants. $/ \eta /$ and $/ \mathrm{h} /, / \pm /$, and $/ \mathrm{x} /$ do not cluster with other consonants initially or finally. $/ \mathrm{T}$ and $/ \mathrm{h} / \mathrm{ap}-$ pear to act importantly as boundary markers of syllables and/or morphemes. /2/, at least, is sometimes retained when suffixes are added. /f/ seems to derive historically from a rounded velar fricative. Clustering patterns are simple, clusters of two consonants being the largest to occur initially or finally. Initially, obstruent plus obstruent, fricative, or resonant, or fricative plus obstruent or resonant, may occur; finally, disregarding glottal stop plus consonant, only resonants and obstruents occur.

Several vowels have rather skewed distributions. None are common initially, and no diphthong is found initially except /ui/. Long vowels tend to be found stressed rather than unstressed, but this is only a tendency. Stress entirely conditions length only for /ai/ ([ai] is unstressed, $\left[a^{\cdot} \cdot 1\right]$ is stressed).

[ə] is non-phonemic,-occurring as an epenthetic vowel, with syllabic nasals, and as a substitute for other vowels (especially /i/) in unstressed position.

Phonemic stress occurs on the first syllable of stems, and is accompanied by higher (or perhaps sometimes by lower) pitch. other information concerning pitch and intonation is substantially lacking.

The canonical form of syllables is $(C) V(C)$, in which $C=$ one or two 
consonants and $\mathrm{V}=$ long or short single vowels or diphthongs, or nasals. The probable segmental phonemes, then, are the following:

\section{Consonants}

\section{Plain Glottalized ${ }^{\text {Obstruents }}$ Fricatives Resonants Glides}

\begin{tabular}{|c|c|c|}
\hline Labial & $\mathrm{p}$ & $\stackrel{\dot{p}}{ }$ \\
\hline \multirow{2}{*}{$\begin{array}{l}\text { Alveo-dental, } \\
\text { Alveo-palatal }\end{array}$} & $\mathrm{t}$. & $t$ \\
\hline & c & '́ \\
\hline Velar & $\mathrm{k}$ & $\vec{k}$ \\
\hline Labiovelar & $k^{w}$ & $\mathrm{k}^{\mathrm{w}}$ \\
\hline Glottal & & $?$ \\
\hline
\end{tabular}

Vowels

Diphthongs

Front Center Back

High $i \quad i \cdot$

$\mathrm{u} u$ •

ai

ni

Low

a $a \cdot$

au $\mathrm{a} \cdot \mathrm{u}$

The Areal Context

The interpretation of Mary's River Kalapuyan phonology offered tentatively here has presented a rather simple system, compared to others in the Northwest. In particular, glottalization, while not as sporadic and. unpredictable as Shipley claimed ("their occurrence is entirely unsystematic" [1969:227-228]; Jacobs rightly objected to "this conclusion about glottalizations ... popping and crackling unpredictably here and there" [1970:67]), is not as important as it is in other regional languages; neither do the consonant clusters reach the size they attain elsewhere.

It is of some interest to look at the phonemic systems of 
neighboring languages. Molala appears to be highly similar to Mary's River, to judge by Rigsby's (1969:144) phonemicization of Frachtenberg's Molala. There are two series of obstruents, glottalized and unglottalized ( $p, t, c, k, q$, however, not $p, t, c, k, k^{w}$ ); Molala lacks an $/ x /$, but the other fricatives are the same; the resonants are the same except for the addition of $/ \mathrm{h} /$. There are four vowels, with length phonemic. At a brief glance, the clusters look rather like Mary's River; Rigsby has only a table of phonemes and does not discuss clusters or other phenomena. In the Northwest, the /ff/ is shared only by Molala and Kalapuyan. The remarkable similarity in phonemic structures is not paralleled by the same degree of lexical or grammatical similarity, however.

The related Takelma, as presented by Shipley (1969), has three series of stops, glottalized, aspirated, and plain, at the same articulatory positions as Kalapuyan (except that /c/ does not occur aspirated). It lacks the $/ f /$ and $/ Z /$, but the other fricatives and resonants are the same. There are five vowels, with length phonemic, and two pitches. Shipley appears to treat the diphthongs as vowel plus $/ w /$ or $/ y /$. This system too is much like Mary's River, if the aspirated stops are ignored.

Phonemic analyses are not available for all of the Oregon Coast langtages, but Pierce (1971) reports, for Hanis Coos, three vowels plus length, diphthongs (number unspecified), and three complex-appearing obstruent series--voiceless, voiced, and glottalized--with three sets of affricates and two velar distinctions. Consonant clusters are not discussed. There is, in short, not much resemblance to Kalapuyan other than the vowels. 
Chinookan is noted for its exuberance of Northwest-appearing clusters and glottalized consonants; in this respect, it is unlike Kalapuyan also.

Scherzer's discussion of areal traits for North American Indian languages (1973:766-773) is helpful in trying to relate Kalapuyan to other languages of the area, though his concern is not to present entire phonemic systems for particular.languages. According to the traits he presents, Kalapuyan seems closer to the Plateau area phonologically, and somewhat less close to the Northwest Coast (Scherzer treats these separately but considers them part of a single linguistic area). California and the Great Basin, other possible regional affiliations, do not seem particularly close.

of the șix phonological features Scherzer lists as "central area traits" of the Plateau, all but the last are found in Mary's River. The six are: glottalized stop series, a q sound, labiovelars phonemically distinct, one fricative series, velar fricatives, and the sounds 1,7 ,

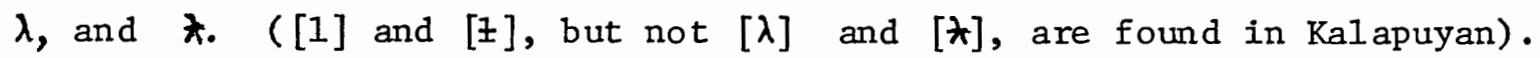
He mentions two other traits as rarely found outside the Plateau: pharyngeal phonemes and glottalized continuants. The first is not found in Kalapuyan, the latter is, though not phonemically. The six Plateau area traits and the two typical ones are also shared by the Northwest Coast, which has in addition $s / \check{s}$ and $c / \check{c}$ oppositions; these are not found as phonemic distinctions in Mary's River, nor is the $[\lambda]$, which is not a central area trait but is seldom fourd outside the Northwest Coast. Both Northwest Coast and Plateau are said to lack languages (except Kutenai) with one stop series and voiced fricatives. 
Similarities to Molala and to the Plateau are not in the least surprising, since it is well known that phonological features can spread across lines of genetic relationship, and indeed have done so in the Northwest. Similarities in phonological features thus indicate more about communication networks than about common ancestral ties. In particular, the degree of similarity to Molala would seem to indicate a rather high degree of social interaction between Kalapuyan and Molala speakers over a considerable period of time. Perhaps a closer examination of phonological systems in surrounding areas could shed light on former historical contacts between Kalapuyan speakers and other groups.

\section{Conclusion}

My analysis is not a complete solution of Mary's River phonology; a number of uncertainties remain. It is only a beginning step in the understanding of the Kalapuyan 1anguages. A necessary next step must be a description of the morphology; this will be of considerable help in solving some phonological problems. The other two Kalapuyan languages remain to be described, as well; the relationships between the three, and internal dialect differences and relationships, have to be dealt with. Eventually, I hope, the genetic relationships within Takelman, and between Takelman and other Penutian languages, can be worked out. 


\section{BIBLIOGRAPHY}

Applegate, Jesse

1930 Recollections of My Boyhood. In Maude A. Rucker, The Oregon Trail, 85-218. New York: Walter Neale.

Barnhardt, W. H.

1859 [Umpqua, Takelma, and Kalapuya Vocabularies.] Ms. 218, National Anthropological Archives. Washington, D. C.: Smithsonian Institution.

Boas, Franz, Pliny Earle Goddard, Edward Sapir, A. I. Kroeber

1916 Phonetic Transcription of Indian Languages. Report of Committee of the American Anthropological Association. Smithsonian Miscel1aneous Collections 66:6:1-15.

Callaghan, Catherine

1958 California Penutian: History and Bibliography. IJAL 24:3: 189-194.

de Angulo, Jaime, and L. S. Freeland

n.d. The Tfalati Dialect of Kalapuya. Unpublished ms. Box 71.3, Melvilie Jacobs Collection. University of Washington Library.

Dixon, Roland and A. L. Kroeber

1919 Linguistic Families of Califormia. University of California Publications in American Archeology and Ethnology 16:3:47-118.

Frachtenberg, Leo J.

n.d. Coyote as the Culture Hero. Typescript. Box 70.9, Melville Jacobs Collection. University of Washington Library.

1913a [Kalapuya. Ethnology.] Ms. 1923-c, National Anthropological Archives. Washington, D. C.: Smithsonian Institution.

1913b [Yamhill.] 3 vols. Ms. 1923-e, National Anthropological Archives. Washington, D. C.: Smithsonian Institution.

1913-14a Kalapuya Texts (Mary's River Dialect). Vols. 1-13. Ms. 1923-a, National Anthropological Archives. Washington, D. C.: Smithsonian Institution.

1913-14b Notes to Texts. Vols. 1-3. Ms. 1923-b, National Anthropological Archives. Washington, D. C.: Smithsonian Institution.

1913-14c Grammatical Notes. Vols. 1-3. Ms. 1923-c, National Anthropological Archives. Washington, D. C.: Smithsonian Institution. 
1914 [Yonkalla.] Ms. 1923-f, National Anthropological Archives. Washington, D. C.: Smithsonian Institution.

1918a Comparative. Studies in Takelman, Kalapuyan, and Chinookan Lexicography: A Preliminary Paper. IJAL 1:2:175-182.

1918b Myths of the Alsea Indians of Northwestern Oregon. IJAL 1:64-75.

1922a Coos. In Franz Boas, ed., Handbook of North American Indian Languages, Part 2 (BAE Bulletin 40) 297-429.

1922b Siuslawan (Lower Umpqua). In Franz Boas, ed., Handbook of North American Indian Languages, Part 2 (BAE Bulletin 40) 431-629.

Gatschet, Albert S.

1877a Indian Languages of the Pacific States and Territories. Magazine of American History $1: 145-171 ; 8: 253-263$.

$1877 \mathrm{~b}$ Texts, Sentences and Vocables of the Atfalati Dialect of the Kal apuy a Language ....8 unpublished notebooks. Ms. 472-a-b-c, National Anthropological Archives. Washington, D. C.: Smithsonian Institution.

1877c Lúkamiute and Ahántchuyuk dialects of the Kalapúy a family. Ms. 473, National Anthropological Archives. Washington, D. C.: Smithsonian Institution.

1877d Yamhill, of Kalapuya family. Ms. 474, National Anthropological Archives. Washington, D. C.: Smithsonian Institution.

1877e Wápatu Lake Indians or Atf́alati. Ms. 472d, National Anthrapological Archives. Washington, D. C.: Smithsonian Institution.

1899 Various Ethnographic Notes. JAFL 12:208-214.

Gibbs, George

1851 Callapooya: Yamhill Dialect. Ms. 475-a-b, National Anthropological Archives. Washington, D. C.: Smithsonian Institution.

Gleason, H. A.

1961 An Introduction to Descriptive Linguistics. New York: Holt, Rinehart and Winston.

Hale, Horatio

1846 United States Exploring Expedition During the Years 1838, 1839, 1840, 1841, 1842. Vo1. 6: Ethnography and Philology. Philadelphia: Lea and Blanchard.

Hymes, Dell

1956 Review of Papers from the Symposium on American Indian Linguistics Held at Berkeley July 6, 1951 (U.C.P.L. 10:1-68), 1954. Language 32:585-602. 
1957 Some Penutian Elements and the Penutian Hypothesis. SWJA 13: 69-87.

1964 Evidence for Penutian in Lexical Sets with Initial $*_{C}-$ and $*_{S}$-. IJAL 30:213-242.

1966 . Some Points of Siuslaw Phonology. IJAL $32: 4: 328-342$.

Jacobs, Melville

n.d. [An Autobiography of Louis Kenoyer.] Unpublished ms. Box 71.1, Melville Jacobs Collection. University of Washington Library.

1930 A Grammatical Sketch of the Kalapuya Dialects. Unpublished ms. Box 70.2, Melville Jacobs Collection. University of Washington Library.

1945 Kalapuya Texts. University of Washington Publications in Anthropology 11 .

1970 Resources in Kalapuyan Languages. IJAL 36:1:67.

Lisker, Leigh

1946 Review of Melville Jacobs. IJAL 12:3:178.

Longacre, Robert E.

1960 Review of Mauricio Swadesh, Mapas de Clasificación linglística de México y las Américas. Language 36:3:397-410.

Parker, Rev. Samuel

1838 Journal of an Exploring Tour Beyond the Rocky Mountains. Ithaca, N. Y.

Pierce, Joe

1965a Computer Analysis of Alsea. IJAL 31:2:128-31.

1965b Hanis and Miluk: Dialects of Unrelated Languages. IJAL 31:4: $323-325$.

1966 Genetic Comparisons and Hanis, Miluk, Alsea, Siuslaw, and Takelma. IJAL 32:4:379-387.

1971 Hanis (Coos) Phonemics. Linguistics 75:31-42.

Pike, Kenneth

1963 Phonemics. Ann Arbor: University of Michigan Press.

Pitkin, Harvey and William Shipley

1958 A Comparative Survey of California Penutian. IJAL 24:3:174-188. 
Powe11, J. W.

1891 Indian Linguistic Families North of Mexico. Bureau of Ethnology 7th Annual Report, 1-142. Washington, D. C. : Government Printing Office.

Preston, W. D.

1946 Problems of Test Attestation in Ethnography and Linguistics. IJAL $12: 173-177$.

Rigsby, Bruce

1966 On Cayuse-Molala Relatability. IJAL 32:4:369-378.

1969 The Waillatpuan Problem: More on Cayuse-Molala Relatability. NARN $3: 1: 68-146$.

Rumberger, J. P.

1949 Ethnolinguistic Observations Based on Kalapuya Texts. IJAL 15: $3: 158-162$.

Sapir, Edward

1912 The Takelma Language of Southwestern Oregon. BAE Bulletin 40: $2: 7-296$.

1921 A Characteristic Penutian Form of Stem. IJAL 2:58-67.

1929 Central and North American Languages. Encyclopedia Brittanica (14th ed.) 5:128-141. Reprinted in David Mandelbaum, ed., Selected Writings of Edward Sapir, 168-178. Berkeley: University of California Press, 1951.

Sapir, Edward and Morris Swadesh

1946 American Indian Grammatical Categories. Word 2:103-112.

1953 Coos-Takelma-Penutian Comparisons. IJAL 19:132-137.

Scherzer, Joel

1973 Areal Linguistics in North America. In Thomas Sebeok, ed., Current Trends in Linguistics 10:749-795. The Hague: Mouton.

Shipley, William

1966 The Relation of Klamath to California Penutian. Language 42:2: 489-498.

1969 Proto-Takelman. IJAL 35:3:226-230.

1970 Proto-Kalapuyán. In Earl H. Swanson, Jr., ed., Languages and Cultures of Western North America: Essays in Honor of Sven $S$. Liljeblad, 97-106.

Swadesh, Morris

1954 On the Penutian Vocabulary Survey. IJAI 20:2:122-133. 
1956 Problems of Long-Range Comparison in Penutian. Language 32:1: $21-41$.

1965 Kalapuya and Takelma. IJAL 31:237-240.

Thompson, Laurence C.

1973 The Northwest. In Thomas Sebeok, ed., Current Trends in Linguistics 10:979-1045. The Hague: Mouton.

Voegelin, Carl

1959 Review of North American Indian Languages: Classification and Maps, by Trager and Harden (SIL Occasional Papers 5) 1958. Language $35: 2: 385-388$.

Voegelin, Carl and Florence M. Voegelin

1964 Penutian Phylum. Languages of the World: Native America Fascicle One (Anthropological Linguistics 6:6) 119-128.

1965 Classifications of American Indian Languages. Languages of the World: Fascicle Two (Anthropological Linguistics 7:7) 121-139.

1966 Map of North American Indian Languages. American Ethnological Society Publication 20.

1967 Review of Die Nordamerikanischen Indianersprachen: ein Uberblick luber ihren Baumdehre Besonderheiten by Heinz-Jurgen Pinnow. Language 43:573. 
Mary's River texts, Vol. I, p. 2. Page 2 of "Coyote and the Gamblers"

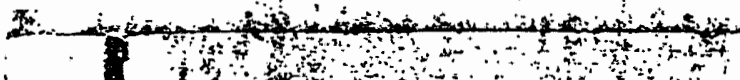

ind

10

10

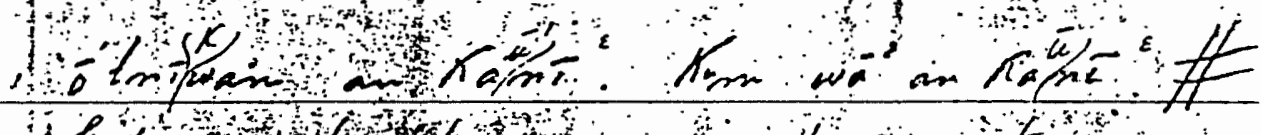

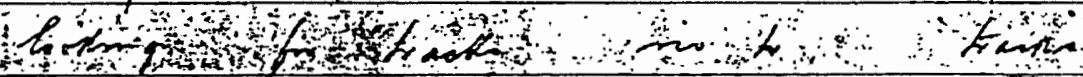

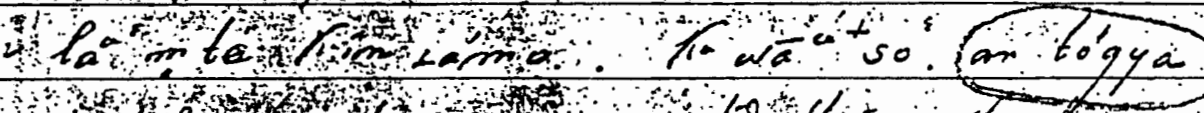

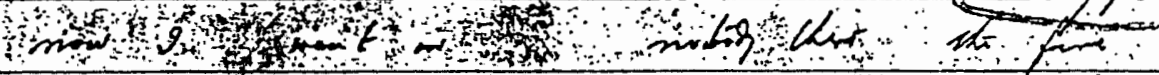

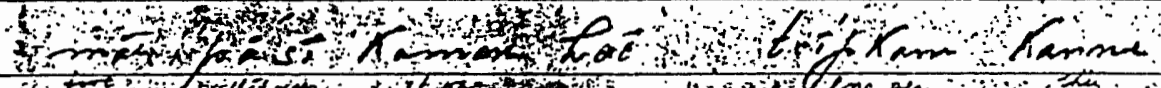

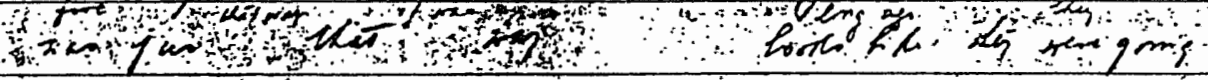

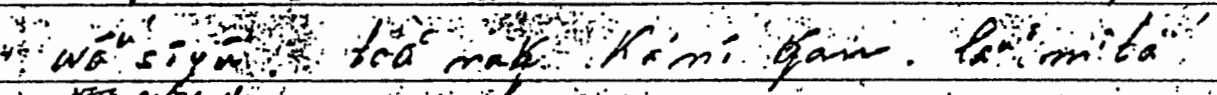

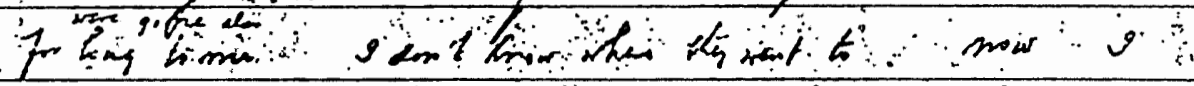

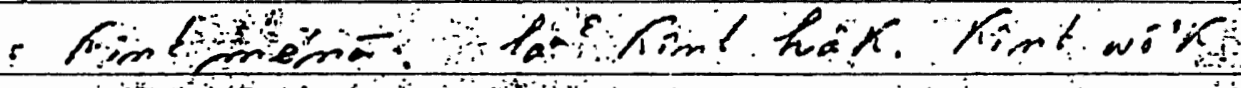

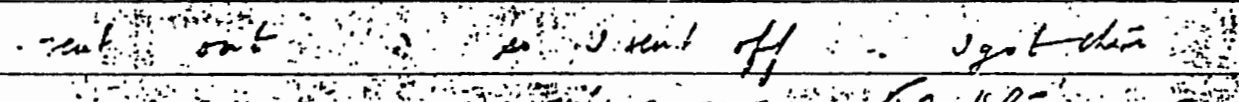

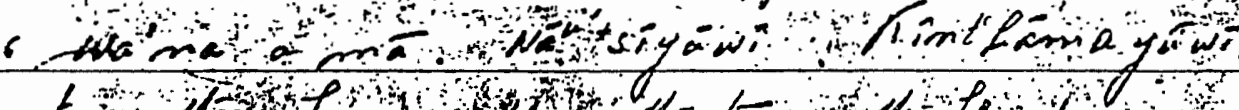
1. an thas form

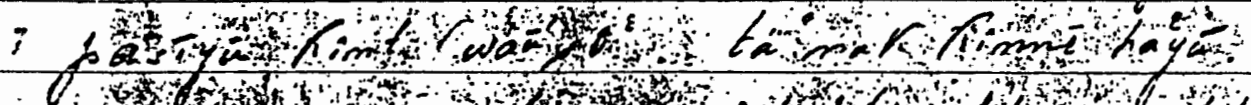

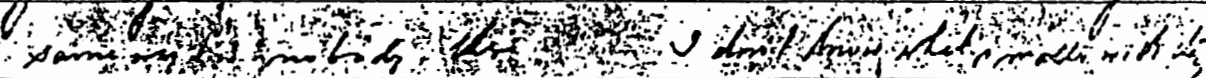

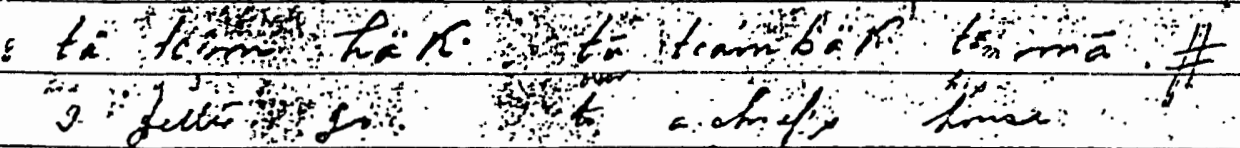

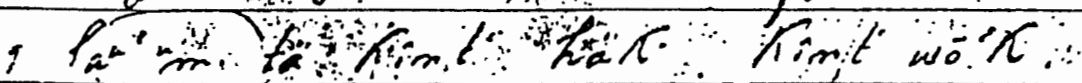

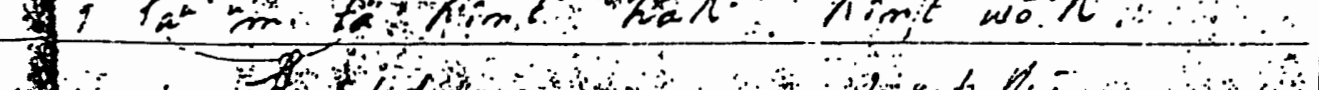
$.71 \therefore$ s. 


\section{APPENDIX}

The preceding page is a copy of page two of the first volume of the Mary's River texts, and is a fair sample of the Frachtenberg manuscripts. Following is a list of the forms on this page, together with variants of the forms found elsewhere in the manuscripts, and the number of times each one occurs. Modal forms, if they exist, are starred. I have provided a phonemic transcription for each form; in some cases I am not sure if the transcription is correct.

an (not tallied; three instances on page 2 alone)

$\underline{\sigma \cdot \operatorname{tni} \cdot k w a n}(1)$

pá.si. (1)

$$
\frac{\mathrm{pás} \cdot i \cdot(1)}{\underline{\mathrm{pa} \cdot \mathrm{si}}} \text { (1) }
$$

pási·yu· (2)

pas.i.yu.

thㄷ (2)

th $(16)$ *

th.

$\overline{\mathrm{te}}$ (1)

tEm (32)

$\underline{\mathrm{tu}} \cdot(49)$

tóqya (1)

tcîn (9) *

tcim (2)

$\overline{t c \cdot i m}$ (1)

$-\overline{\text { tcEm }}(1)$

tcum - (1)

tcí.pkam (8) *

tcl.pkan

(1) "the" (noun prefix) /an/

"looking"

$/ \dot{u} \cdot \operatorname{tni} \cdot \mathrm{k}^{\mathrm{w}}$ an $/$

"thus"

/pá·si•/?

"thus also"

/pási·yu·/

"I (?); how" /ti/

"his, her; my (?)" / / $\frac{m}{1}$

"to, over, in, from" /tu•/

"fire" /túkya/

"I'd better, I will" /cm/, 
tcámbHk. (1)

tcámbek (1)

"chief"

/cámpik/

tc.ámbek - (1)

tcámbek- (16) *

tcambak (1)

tcámpHk - (1)

tsámbek- (2)

tsambek (1)

tcos (3)

tco (1)

"where"

/cuh/

tcos (14) *

tc.or (3)

tc.o (3)

tc.o

ts.o? (1)

tsu' (1)

$\mathrm{k}^{\mathrm{u}} \mathrm{m}(493) *$

kum (116)

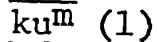

kEm (1)

qan (16)

"went"

/kan/

kamán (6) *

kamân (1)

"he, it was (?)" $/ \mathrm{k}^{\mathrm{w}_{\mathrm{m}}} /$

káni· (4)

kanne (4)

kane (1)

kanni (2)

"will be; was" /kamán/

"they (go?)"

/káni/ ?

kînne (2)

kinne (12)

"they are". (?)

/kínil ?

kinne (17)

k.inne (1)

k. Inne (5)

kine (118) *

kine (36)

k. Ine (28)

k.ine (48)

kint (71) *

$\mathrm{k}$. Ant (48)

"I, he, (we?) went" / kint/

$\overline{\text { kint }}$ (13)

$\overline{\text { kint }}$ (45)

k. int $\mathrm{i}$ (1)

$\overline{\mathrm{k} \cdot \mathrm{int}}$ (7)

$\mathrm{kaú} \cdot \mathrm{ni} \cdot(6) \doteqdot$

$\mathrm{ka} \hat{u}_{\mathrm{ni}} \cdot ?(1)$

\footnotetext{
"road, tracks" /ká·uni·r/
} 


$$
\begin{aligned}
& \mathrm{ka} \cdot \mathrm{u} \cdot \mathrm{ni} \cdot ? \text { (2) }
\end{aligned}
$$

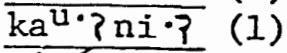

$$
\begin{aligned}
& \mathrm{k}^{1} \mathrm{a}_{\mathrm{u} i \cdot ?} \text { (1) } \\
& \text { kraunir (1) } \\
& \text { k'au'ni. (1) } \\
& \text { kaúni- (3) } \\
& \text { ḱaúni (1) }
\end{aligned}
$$

hoi. (1)

ho.i (12) *

ha? $\mathrm{yu}^{\text {. (I) }}$

h4kk (32) *

hakk (1)

hम्म.k. (10)

haik (1)

ha.ik. (1)

$$
\frac{\text { ma. }}{\text { (68) }} \text { * }(2)
$$

$\underline{m a} i^{\prime} \cdot(1)$

mai. (2)

maì (1)

ma. (11) *

ména. (1)

nak (164)

$$
\begin{gathered}
\frac{1 a^{u} ?(87) *}{1 \cdot a^{u} ?}(2) \\
\frac{1 a^{u} \cdot(1)}{1 a^{u}}(1)
\end{gathered}
$$

$$
1 \mathrm{a}^{\mathrm{u}} \text { m mt }
$$$$
1 a^{47 u_{\text {mt }}} \text { (1) }
$$$$
\text { 1au?mîttम (2) }
$$$$
\text { 1a.4mta (1) }
$$$$
\text { 1aumt }
$$$$
\text { 1a.unty (1) }
$$$$
\text { 1au?mtम (42) }
$$$$
\text { 1a.4?mty (2) }
$$$$
1 \mathrm{a}^{\mathrm{m}} \text { म }
$$$$
\text { 1a.4?umty (1) }
$$

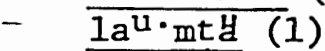$$
1 \mathrm{a}^{\mathrm{U}} \mathrm{pm}^{\mathrm{T}} \mathrm{t} \text {. }
$$$$
\text { 1aumity (3) }
$$$$
\text { I. a } a^{u} \text { mty (1) }
$$

$$
\text { "be" }
$$

/hui/

$?$

"went on, go" /ha? yu $/ /$

/hik/

"house"

$/ \mathrm{ma} \cdot /$

$$
\begin{aligned}
& \text { "fire" } \\
& \text { (house?) }
\end{aligned}
$$

/mai/ ?

$$
\text { "out" }
$$

/ména · /

"say, said"

/nak/

"then, now"

/1au? /

"then, now (I?)"

/ laứpmti/ 
1a.ámt

1ámt

$\overline{1 \cdot a \cdot m^{ \pm}}$(2)

1a.mt倠 (2)

$\overline{1 a \cdot \mathrm{mEt} h}$ (1)

$\overline{1 \cdot a \cdot m t^{4}}$ (115)

1.a.mith (4)

$\overline{1 a \cdot m^{2}+4}$ (4)

1a.mt

lamth (1)

I-a.mt

Lámo (2)

Lámo (1)

"inside"

/ 1á·mu/

$\overline{1 \mathrm{a} \cdot \mathrm{mo}}$ (30) *

1ámo (1)

Ílamo (1)

1द? mo (1)

至mo (1)

Lá.ma (1)

wo. "k (58) *

wo. ?k (1)

wo?k (1)

"there" / /

wa? na (13) *

wánal (2)

watna (1)

$\frac{\text { wa }{ }^{\text {G. sô? }}}{\text { wa. }} \cdot(1)_{\text {so? }}$ (2)

"nobody" / / / /

wa. पsô? (1)

wa.ut. so? (3)

wat.(.) so? (3)

"to another" /wá?na/

$\mathrm{k}^{\mathrm{u}_{\text {wa }} \cdot \overline{\mathrm{u}}(\cdot) \text { so? (1) }}$

kuwal. $\left.(\cdot)_{s} \cdot 0\right\}(1)$

kuwa ${ }^{4} \cdot(\cdot)$ so? (2)

kuwat?.(.) $s \cdot u \cdot ?(1)$

"nobody is there" /kuwáusu?/ ?

wa.úl.) si.yu. (1)

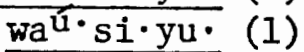

"nobody there also" /wá.usi.yu·/

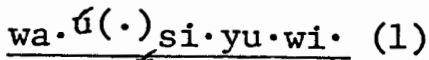

wa. a.si.ŷti.

"nobody there also /wá.usi·yu·wi·/ ? indeed"

"no, not" /wa?/

wa.

wa? $(102)$ *

yú.wi. (8)

yú.wî̀ (8)

"again"

/yú·wi·/ ? 


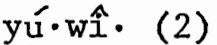

hyú.wi. (1) 